\title{
Interplay between the endocrine and circadian systems in fishes
}

\author{
Esther Isorna, Nuria de Pedro, Ana I Valenciano, Ángel L Alonso-Gómez and \\ María J Delgado
}

Departamento de Fisiología (Fisiología Animal II), Facultad de Biología, Universidad Complutense

de Madrid, Madrid, Spain
Correspondence should be addressed to E Isorna

Email

eisornaa@bio.ucm.es

\begin{abstract}
The circadian system is responsible for the temporal organisation of physiological functions which, in part, involves daily cycles of hormonal activity. In this review, we analyse the interplay between the circadian and endocrine systems in fishes. We first describe the current model of fish circadian system organisation and the basis of the molecular clockwork that enables different tissues to act as internal pacemakers. This system consists of a net of central and peripherally located oscillators and can be synchronised by the light-darkness and feeding-fasting cycles. We then focus on two central neuroendocrine transducers (melatonin and orexin) and three peripheral hormones (leptin, ghrelin and cortisol), which are involved in the synchronisation of the circadian system in mammals and/or energy status signalling. We review the role of each of these as overt rhythms (i.e. outputs of the circadian system) and, for the first time, as key internal temporal messengers that act as inputs for other endogenous oscillators. Based on acute changes in clock gene expression, we describe the currently accepted model of endogenous oscillator entrainment by the light-darkness cycle and propose a new model for non-photic (endocrine) entrainment, highlighting the importance of the bidirectional cross-talking between the endocrine and circadian systems in fishes. The flexibility of the fish circadian system combined with the absence of a master clock makes these vertebrates a very attractive model for studying communication among oscillators to drive functionally coordinated outputs.
\end{abstract}

Key Words
- circadian rhythms
- clock genes
- glucocorticoids
- ghrelin
- leptin
- melatonin
- orexin

Journal of Endocrinology (2017) 232, R141-R159

\section{Introduction}

The circadian system is responsible for the temporal organisation of several physiological, metabolic and behavioural activities, allowing the functioning of animals to be synchronised with predictable environmental changes (i.e. zeitgebers). The light-darkness (LD) cycle is the most important external zeitgeber for the vertebrate circadian system (Hastings et al. 2007, Albrecht 2012, Schibler et al. 2015), but food availability (Stephan 2002, Albrecht 2012, Patton \& Mistlberger 2013) and temperature cycles
(Buhr et al. 2010, Poletini et al. 2015, Schibler et al. 2015) are also important. These environmental factors are considered the 'inputs' of the circadian system, whereas the rhythms that are generated are called the 'outputs' or 'overt rhythms'. The circadian system is composed of a third element, the core clock, which is synchronised by the inputs and drives the outputs (Hastings et al. 2007, Albrecht 2012).

Daily locomotor activity and hormonal rhythms are two of the most studied outputs of the circadian system 
in vertebrates. The dependence of melatonin, pituitary hormone and glucocorticoid rhythms on the LD cycle has been studied for decades in mammals (Pevet \& Challet 2011, Kalsbeek et al. 2012, Lin et al. 2015) and fishes (Falcón et al. 2007, 2010). However, it is known that many other hormones and neuropeptides (orexin, ghrelin, leptin and insulin) also exhibit daily oscillations (Patton \& Mistlberger 2013, Tinoco et al. 2014, Challet 2015, Sánchez-Bretaño et al. 2015a, Schibler et al. 2015). Circadian clocks were once thought to be located only in the central nervous system. However, increasing evidence suggests that the circadian system is formed by a network of central and peripheral oscillators (including endocrine organs; Fig. 1) that are coordinated to drive the overt rhythms (Albrecht 2012, Schibler et al. 2015). In this more complex model of circadian organisation, hormones can not only directly control the circadian outputs but also participate in the synchronisation of other timekeepers, as shown in Fig. 1. This concept has been well-developed in mammals (Albrecht 2012, Patton \& Mistlberger 2013,
Challet 2015, Schibler et al. 2015), but remains practically unexplored in fishes.

In this review, we analyse the interplay between the circadian and endocrine systems in fishes. We first describe the current model of fish circadian system organisation. We then focus on two central messengers (melatonin and orexin) and three hormones (ghrelin, leptin and cortisol) due to their importance in synchronising the circadian system in mammals and/or their recognised roles as nutritional status signals (Pevet \& Challet 2011, Albrecht 2012, Patton \& Mistlberger 2013, Challet 2015, Schibler et al. 2015). We consider these hormones as outputs, reviewing what is known to date about the origin of their rhythmicity and also as putative inputs, whereby they act as temporal endogenous messengers that may entrain endogenous clocks.

We do not discuss other important endocrine rhythms in fishes, such as the reproductive hormones, because they have been reviewed previously (Bromage et al. 1990, Falcón et al. 2010, Migaud et al. 2010,

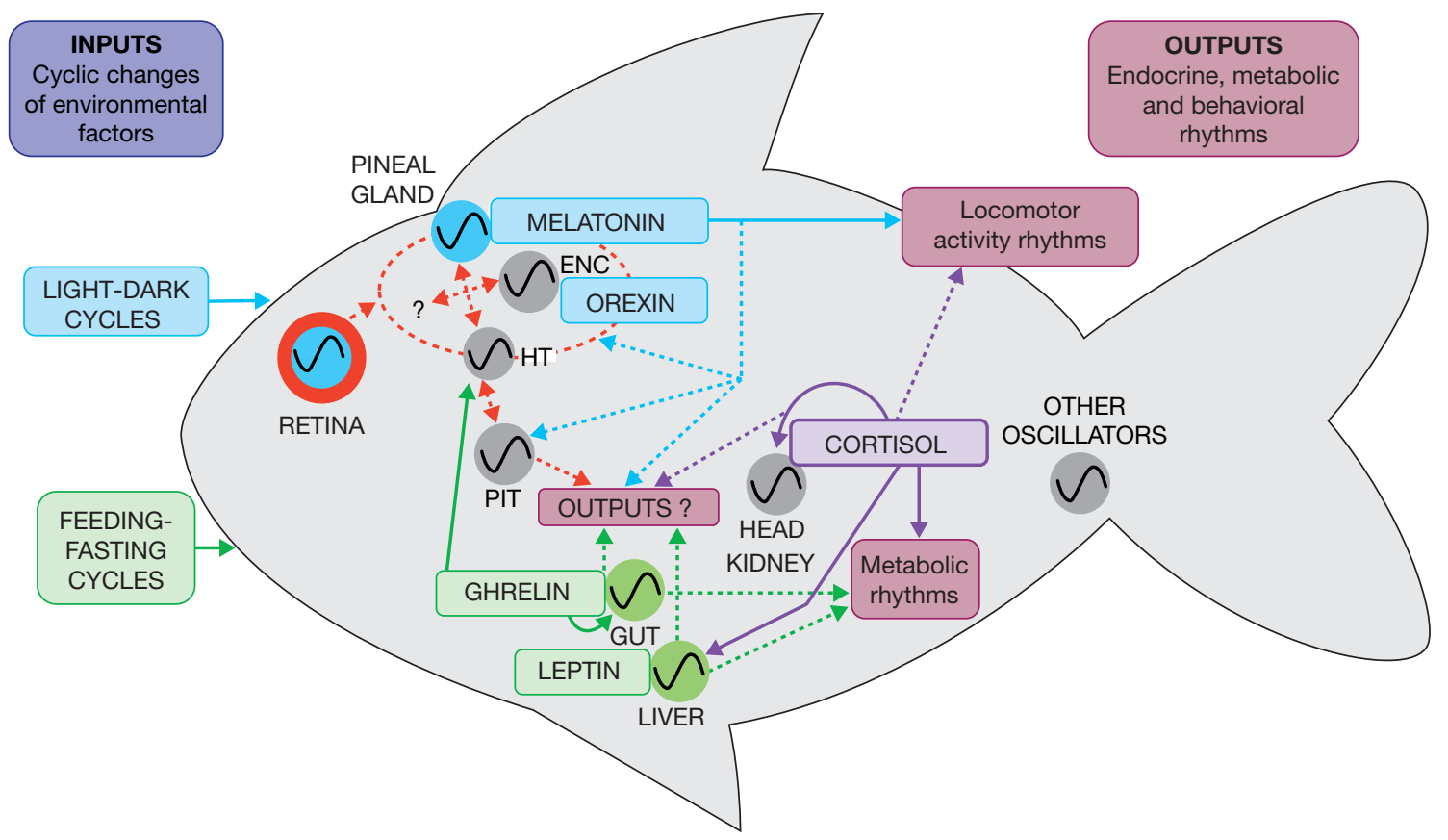

\section{Figure 1}

The fish circadian system: a net of circadian oscillators. The fish circadian system is composed of a net of oscillators that are widely distributed throughout the entire organism. These oscillators are entrained by external inputs, such as the light-darkness and feeding-fasting cycles and should be linked to generate outputs (such as locomotor activity and metabolic rhythms) in a coordinated manner. The retina, pineal gland and probably some deep brain photoreceptors are directly targeted by light, which then entrains the endogenous clocks in such structures (shown in blue). Other organs that contain circadian clocks, such as the gut and liver, are probably targeted by any feeding- or metabolic-related signals, which mainly synchronise these oscillators to the energetic status of the animal (shown in green). The head kidney is probably entrained by both external signals (shown in purple). These endocrine organs (pineal gland, pituitary gland, gut, liver and head kidney) release hormones (melatonin, pituitary hormones, ghrelin, leptin and cortisol) in a time-dependent pattern, which may provide a temporal message to specific-hormone receptors. This diagram only shows the most studied endocrine organs that are functionally related to the circadian system; however, other oscillators also probably exist. The continuous lines indicate the connections that are currently known to exist in fishes, whereas the dashed lines illustrate hypothetical connections that have not yet been reported. ENC, other encephalic nuclei; HT, hypothalamus; PIT, pituitary gland. For more information, see the text. 
Nakane et al. 2013, Nishiwaki-Ohkawa \& Yoshimura 2016) and because the role of gonadal hormones as internal inputs in fishes has been less explored than other hormones to date (Nakane et al. 2013, Martins et al. 2015, Takeuchi et al. 2015).

\section{Organisation of the fish circadian system}

The fish circadian system consists of a variety of oscillators that are located in numerous (if not all) tissues (Fig. 1). The molecular functioning of this set of oscillators is similar in peripheral and central clocks and is based on translational-transcriptional feedback loops of a set of genes called clock genes, whose mRNA levels and proteins oscillate on a c. 24-h basis (reviewed in Reppert \& Weaver 2002, Hastings et al. 2007, Albrecht 2012, Schibler et al. 2015). The functioning of the fish molecular clock has been deeply studied in zebrafish (Danio rerio; reviewed in Cahill 2002, Vatine et al. 2011, Idda et al. 2012 and schematised in the core of Fig. 2). The main loop is formed by the positive elements brain and muscle ARNT-like 1 (Bmal1) and circadian locomotor output cycles kaput (Clock), which form a heterodimer

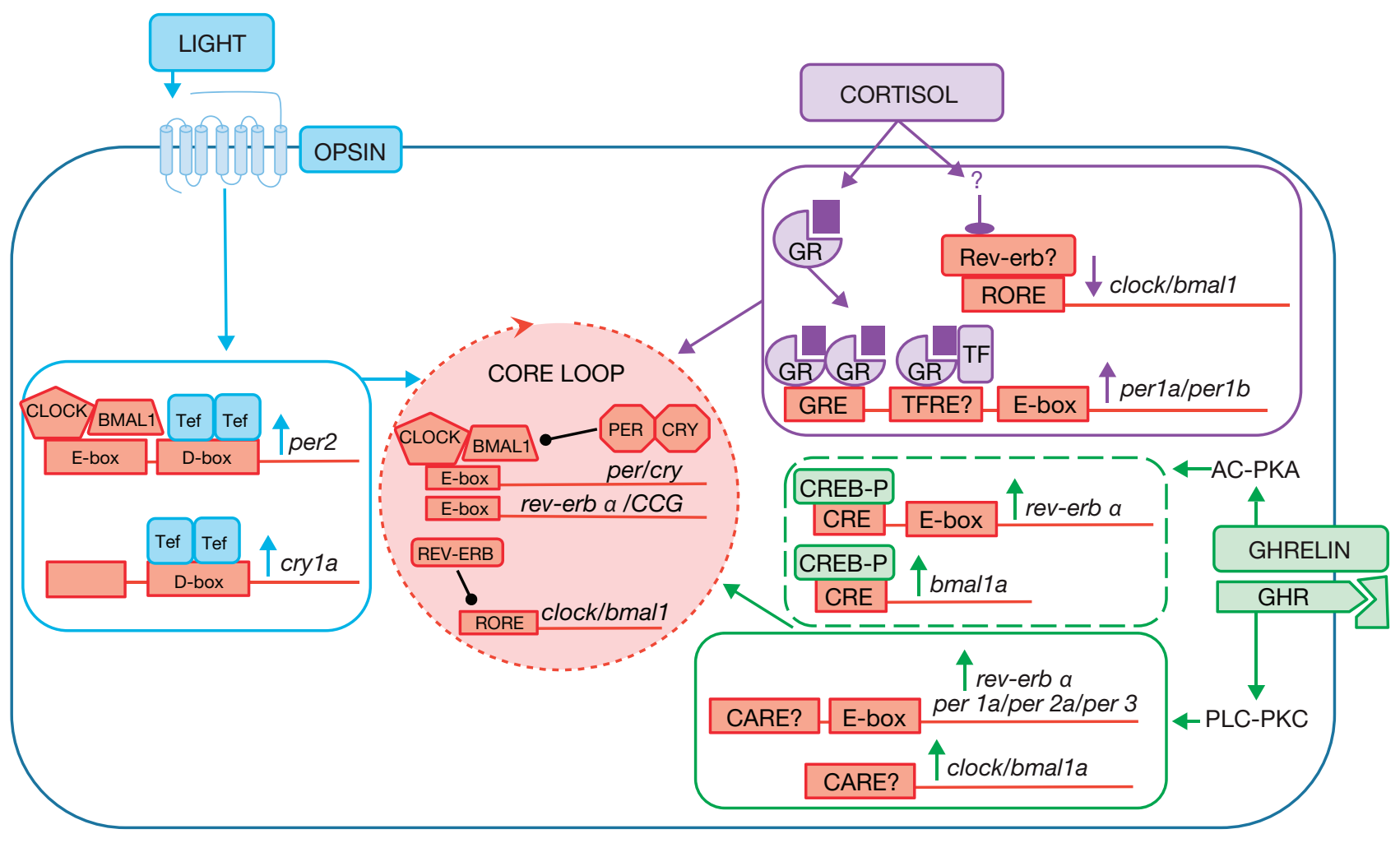

PHOTIC ENTRAINMENT

NON PHOTIC ENTRAINMENT

Figure 2

Hypothetical model of entrainment of circadian oscillators by light and hormonal inputs in fishes: putative mechanisms for the synchronisation of endogenous clocks. The molecular core of the endogenous oscillators is thought to be synchronised by exogenous (light) or endogenous (hormones) temporal messengers through the induction or repression of specific clock genes (for more information, see the text). Events that occur in the cytoplasm and nuclei (gene transcription) have not been separated to simplify the figure. In each box, only putative response elements that are involved in each response (light, cortisol or ghrelin) are shown. The molecular core of the clock, i.e. the feedback loops that sustain the $24-\mathrm{h}$ clock gene oscillations, is represented as the central circle in red, with some of the main elements inside. This molecular mechanism can be entrained by the light-darkness cycle via the light-evoked induction of cry1 and per2, which involves functional E- and D-boxes and the Tef transcription factor in zebrafish (Tamai et al. 2007, Vatine et al. 2009, 2011). We also propose alternative mechanisms whereby hormones such as cortisol and ghrelin can entrain the molecular clocks. Cortisol induces per1a and per1b, while repressing bmal1a and clock in the goldfish liver, with this repression possibly being mediated by the Rev-erb transcription factor (Sánchez-Bretaño 2016). Ghrelin induces a variety of clock genes in the goldfish liver (Sánchez-Bretaño A, Blanco AM, Alonso-Gómez $A L$, Delgado MJ, Kah O \& Isorna E, unpublished observations), which is mainly mediated by the PLC-PKC pathway and, to a lesser extent, the AC-PKA pathway (Sánchez-Bretaño 2016). AC-PKA, adenylyl cyclase-protein kinase A; CARE, calcium response element; CCG, clock-controlled genes; CRE, CREB response element; CREB-P, CREB phosphorylated; GHR, ghrelin receptor; GR, glucocorticoid receptor; GRE, glucocorticoid response element; PLC-PKC, phospholipase C-protein kinase C; RORE, RAR-related orphan receptor response element; Tef, thyrotroph embryonic factor; TF, transcription factor; TFRE, transcription factor response element. 
that acts as a transcription activator. This then binds to the E-box regulatory site in the promoter of the negative elements period (per) and cryptochrome (cry) to increase their expression. The dimer Per-Cry in turn inhibits the dimer Clock-Bmal (Reppert \& Weaver 2002, Hastings et al. 2007, Vatine et al. 2011, Albrecht 2012). The ClockBmal heterodimer also induces the expression of genes known as clock-controlled genes, which are considered the outputs of the clock, by binding to the E-boxes in their promoters (Hastings et al. 2007, Vatine et al. 2011, Albrecht 2012). The main loop is stabilised by an auxiliary loop that includes the retinoic acid-related orphan receptor (Ror) and Rev-erb transcription factors, which act through a Ror response element (RORE) site to regulate bmal1 transcription (Guillaumond et al. 2005, Albrecht 2012, Schibler et al. 2015). The functioning of this molecular mechanism is comparable in mammals and teleosts, with the involvement of homologous genes, although several copies of these genes have been reported in fishes (Vatine et al. 2011, Sánchez-Bretaño et al. 2015b).

Daily rhythms in clock genes (an essential property of endogenous clocks) have now been reported in a variety of tissues across several fish species, including the retina, pineal gland, brain, pituitary gland, liver, gut, gonads and head kidney (Park et al. 2007, Davie et al. 2009, Velarde et al. 2009, Huang et al. 2010, López-Olmeda et al. 2010, Cavallari et al. 2011, Patiño et al. 2011, Azpeleta et al. 2012, Martín-Robles et al. 2012, Nisembaum et al. 2012, Vera et al. 2013, Sánchez-Bretaño et al. 2015b,c, Costa et al. 2016; Fig. 1). In these tissues, the transcripts of the positive elements of the core clock (bmal1 and clock1) peak during the photophase, whereas the transcripts of the negative elements (per and cry) increase at the end of the scotophase, as seen in the zebrafish model (Cahill 2002, Vatine et al. 2011). One exception to this pattern is the per2 gene, which is directly induced by light in zebrafish (Vatine et al. 2009) and likely other teleosts (Velarde et al. 2009, Patiño et al. 2011, Nisembaum et al. 2012).

Cell-autonomous and self-sustaining clock gene rhythms have also been described in several cell lines cultured in vitro in zebrafish (Tamai et al. 2005) and cavefish (Phreatichthys andruzzii; Cavallari et al. 2011), but the existence of such widespread oscillations in vivo remains unknown. Recently, high day-night variations in per1b mRNA levels were observed in some diencephalic nuclei of goldfish (Carassius auratus), but no changes were observed in the telencephalon (Sánchez-Bretaño et al. 2015c). Similarly, some brain structures of zebrafish lack some of the core clock genes, even if such areas are photosensitive (Moore \& Whitmore 2014). This suggests that not all brain regions are endogenous oscillators in vivo, highlighting the unresolved organisation of the circadian system in fishes.

It is evident that the organisation of the circadian system in fishes is less hierarchical than that in mammals, where the suprachiasmatic nuclei (SCNs) function as the master clock that entrains other central and peripheral oscillators (Albrecht 2012, Schibler et al. 2015). Such a master clock has not yet been clearly identified in fishes although the pineal gland plays a key role in its circadian system (Cahill 2002, Noche et al. 2011, Idda et al. 2012, Moore \& Whitmore 2014, Sánchez-Bretaño et al. 2015c). Furthermore, the peripheral and central oscillators in fishes appear to be in phase or even more advanced in the peripheral tissues (Cermakian et al. 2000, SánchezBretaño et al. 2015c), suggesting that these pacemakers may be independently synchronised. In some fish species, the locomotor activity patterns are also flexible and dependent on food availability (goldfish; Aranda et al. 2001, Feliciano et al. 2011) or metamorphosis (Senegalese sole, Solea senegalensis; Blanco-Vives et al. 2012). These characteristics of the fish circadian system make the investigation of endocrine signalling in the interplay among endogenous oscillators particularly interesting.

A model of the fish circadian system in which the oscillators are synchronised to different inputs is presented in Fig. 1. The LD cycles would entrain the light entrainable oscillators (LEOs) and the feeding-fasting cycles would entrain the food entrainable oscillators (FEOs). This classification is presented in a functional way, without involving anatomical structures, as the same tissue could be acting as a clock that is entrained by the LD cycles, the feeding-fasting cycles and perhaps other zeitgebers. The dependence of clock gene expression rhythms in the central and peripheral tissues on LD cycles has been demonstrated in a number of teleost species, including zebrafish (López-Olmeda et al. 2010), Atlantic salmon (Salmo salar; Huang et al. 2010), rainbow trout (Oncorhynchus mykiss; Patiño et al. 2011), goldfish (Nisembaum et al. 2012, Sánchez-Bretaño et al. 2015b), sea bream (Sparus aurata; Vera et al. 2013) or Nile tilapia (Oreochromis niloticus; Costa et al. 2016).

LD synchronisation is mediated by acute lightinduced effects on clock gene expression in both mammals (Hastings et al. 2007) and fishes (Cahill 2002, Vatine et al. 2011). Light resets the clock, inducing per2 and cry $1 a$ expression in photosensitive structures via the D-box and E-box elements (Fig. 2; for more information 
see Tamai et al. 2007, Vatine et al. 2009, 2011, Idda et al. 2012). In vitro studies in zebrafish showed that all cells lines are light responsive, including those derived from peripheral tissues such as the heart or liver (Tamai et al. 2005). Furthermore, per 2 and cry $1 a$ are induced by light in multiple brain regions both in vivo and in vitro (Moore \& Whitmore 2014), and rhythmic bioluminescence in per3-luciferase transgenic animals is re-entrained to new LD cycles in explants of encephalic regions (Moore \& Whitmore 2014). However, in the same study, the authors demonstrated that not all brain nuclei are photosensitive, raising the possibility that even in zebrafish, the different oscillators are not as independently entrained by light as initially thought (Moore \& Whitmore 2014). A widespread photosensitive ability may not be a rule in other teleosts as, to date, the existence of photoreceptors has been demonstrated in the pineal gland, retina and deep brain photoreceptors (Menaker et al. 1997, Davies et al. 2015, Hang et al. 2016; blue in Fig. 1), but not in peripheral tissues, although their existence cannot be ruled out (Davies et al. 2015). Indeed, goldfish per2 is not light induced in the liver in vitro (E Isorna, AL Alonso-Gómez $\&$ MJ Delgado, personal observations), suggesting that the liver of this teleost is not light sensitive, matching previous findings for the gut (Nisembaum et al. 2012). Thus, some unknown neural or endocrine messengers that connect photosensitive oscillators to other clocks are likely to exist in fishes. This hypothetical functional organization would enable the entrainment of these clocks to the LD cycle, as occurs in mammals (Hastings et al. 2007, Albrecht 2012, Schibler et al. 2015).

The fish circadian system is also very sensitive to feeding-fasting cycles (Fig. 1). The most robust evidence that rhythms in food availability synchronise the circadian system is the food anticipatory activity (FAA), i.e. the increase of locomotor activity in anticipation of feeding time (Stephan 2002). FAA has been demonstrated in numerous species of fishes, including goldfish (Aranda et al. 2001, Feliciano et al. 2011), zebrafish (López-Olmeda et al. 2010) or sea bream (Vera et al. 2013). Furthermore, it also occurs in the cavefish, which is a blind fish that somehow maintains a molecular clockwork over a c. 47-h period despite lacking entrainment by LD cycles (Cavallari et al. 2011). Thus, the functional organisation of the circadian system is highly adaptive, even when it is synchronised by less canonical zeitgebers such as feeding inputs.

A daily feeding schedule (under constant light) synchronises clock gene rhythms in the optic tectum, hypothalamus, liver and gut in goldfish, at both scheduled meal times, 10:00 and 22:00 (Feliciano et al. 2011, Nisembaum et al. 2012). However, when the LD cycle is present, the rhythms exhibit greater amplitudes, suggesting that both environmental signals work together in sustaining the molecular clockwork, at least in the liver (Nisembaum et al. 2012, Sánchez-Bretaño et al. 2015b). When both zeitgebers (LD and feeding-fasting cycles) are present, the brain oscillators appear to be driven by the LD cycle, whereas the clock gene oscillations in the liver are more dependent on feeding schedule (zebrafish: López-Olmeda et al. 2010; sea bream: Vera et al. 2013). In goldfish, a unique meal may shift the clock gene rhythms in the liver (Feliciano et al. 2011), which matches the findings in mammals, where a high dependence of clock liver entrainment on feeding cues has been reported (Stokkan et al. 2001, Kornmann et al. 2007, Patton \& Mistlberger 2013). Exactly how feeding-fasting cycles entrain endogenous clocks remains unknown, but it is expected that hormones, metabolites or other energy sensor molecules that cycle with feeding status induce acute changes in clock gene expression that shift the clocks (Figs 1 and 2).

\section{Melatonin}

Melatonin (N-acetyl-5-methoxytryptamine) is a major player in controlling biological rhythms in vertebrates. It works as a neuroendocrine signal, transducing environmental information into the circadian system. Plasma melatonin levels show a characteristic nocturnal peak in all studied species, which is an exceptional feature compared with other rhythmic hormones, whose daily profiles are more variable through the 24 -h cycle depending on different factors, such as the active/rest phase and the feeding time, among others. Melatonin nocturnal rhythmic profiles are classified into three types: a discrete peak in the late dark phase, a discrete peak in the mid-dark phase and an expanded peak throughout the dark phase (reviewed in Falcón et al. 2010). It is currently unclear whether these different profiles have functional implications.

Initially, this indole was described as a unique pineal gland metabolite. However, it has now been demonstrated that many other tissues also synthesise melatonin, such as the gastrointestinal tract (Vakkuri et al. 1985, Bubenik \& Pang 1997). Four enzymes are involved in its biosynthetic pathway, with arylalkylamine $\mathrm{N}$-acetyltransferase (AANAT) representing the rate-limiting step (Klein et al. 2002). In Actinopterygii, at least two Aanats exist: Aanat1 (mainly in extrapineal tissues) and Aanat2 (the main

Published by Bioscientifica Ltd. 
enzyme in the pineal gland; Cazaméa-Catalan et al. 2014), which have distinctive enzymatic properties. This peculiarity in the fish melatonin biosynthetic pathway may indicate the differential regulation of the synthesis of this indole depending on the isoform that is expressed in each tissue.

The pineal gland acts as a sensitive photometer that transduces the LD cycle into a hormonal signal, melatonin. In some species, this activity may also be indirectly modulated by other photosensory structures, such as retinal and/or deep brain photoreceptors (Migaud et al. 2006, 2007, Choi et al. 2016). The pineal gland of teleosts (except salmonids) contains all the necessary elements to be considered a real circadian clock, with the complete core machinery (Cahill 2002, McStay et al. 2014). Melatonin secretion may be considered the main output of the pineal clock, which is considered a LEO. Its circadian rhythmicity is maintained under both an $\mathrm{LD}$ cycle and constant darkness conditions in vivo and in vitro (Bolliet et al. 1996, Martinez-Chavez et al. 2008). Salmonids are the exception to this, as rhythmic melatonin synthesis does not occur in the absence of an LD cycle (Bolliet et al. 1996, McStay et al. 2014). A molecular connection between the pineal clockwork and melatonin synthesis has been demonstrated through the existence of an E-box in the aanat 2 promoter that binds the Clock-Bmal dimer (Appelbaum et al. 2006, Falcón et al. 2009, 2010). The retina shares many chronobiological characteristics with the pineal gland and can be considered a melatoninsynthesising molecular clock in some, but not all, fish species. In the cyprinids zebrafish and goldfish, retinal melatonin rhythms are light sensitive and parallel those of the pineal gland (Cahill 1996, Iigo et al. 1997a). However, in rainbow trout (Besseau et al. 2006) and European sea bass (Dicentrarchus labrax; Iigo et al. 1997b), retinal melatonin production peaks during the daytime. Pineal melatonin has free access to the blood, which explains the close correlation between pineal synthesis and plasma melatonin levels and the huge reduction in plasma melatonin that is experienced after pinealectomy (Kezuka et al. 1992, Bayarri et al. 2003), which has very little effect on gut melatonin (Muñoz-Pérez et al. 2016).

Gastrointestinal melatonin has a different cellular origin (enteroendocrine cells; Fernández-Durán et al. 2007, Muñoz-Pérez et al. 2016), but exhibits the same daily rhythmicity in its synthesis as observed for pineal melatonin. However, these daily patterns are particular to each species. For example, in goldfish, gut melatonin synthesis shows a clear circadian rhythm that is in phase with that of the pineal gland (Choi et al. 2016), whereas in Indian carp (Catla catla) it is in antiphase with the pineal and circulating levels (Mukherjee et al. 2014). In fishes, gut melatonin is not synchronised by photic information (e.g. goldfish: Choi et al. 2016), but rather by feeding time, with the acrophase occurring 2-6h after feeding, and the gut melatonin rhythm being maintained after 8 days of starvation in Indian carp (Mukherjee \& Maitra 2015). Similarly, gut melatonin in goldfish also exhibits this dependence on scheduled feeding (Vera et al. 2007). The close correlation between the acrophases of biosynthetic enzymes (aanat2 and hiomt2; Velarde et al. 2010) and clock genes (per1a, per2a and cry3; Nisembaum et al. 2012) in the goldfish hindgut supports the idea that gut melatonin rhythmicity is coupled to a gut molecular clock that may work independently of the pineal clock.

Melatonin acts by binding to melatonin receptors belonging to the G-protein-coupled receptor superfamily (Reppert et al. 1996). These receptors are widely distributed in the fish central nervous system and peripheral tissues (Park et al. 2006, Ikegami et al. 2008, Sauzet et al. 2008), allowing the melatonin circadian message to be broadcast throughout the organism (Fig. 1). In fish, pineal melatonin is acting on some diencephalic areas of the hypothalamus-pituitary neuroendocrine axis (Ekström \& Vanecek 1992), particularly the rostral preoptic area, lateral tuberal nucleus, ventromedial thalamic nucleus and the anterior periventricular nucleus, the putative homologous to the mammalian SCN (reviewed in Falcón et al. 2010). Retinal melatonin mainly has a local role, where it governs some of the daily rhythms, such as retinomotor movements (Zaunreiter et al. 1998) or the modulation of neurotransmitter release (Ribelayga et al. 2004). Melatonin also entrains daily locomotor activity rhythms in mammals (Cassone et al. 1993), but this function has not been clearly demonstrated in fishes. A clear effect on locomotor activity pattern has only been found in some teleosts (goldfish and tench, Tinca tinca: López-Olmeda et al. 2006; European sea bass: Herrero et al. 2007). Moreover, melatonin influences sleep in zebrafish (Elbaz et al. 2013, Gandhi et al. 2015).

Melatonin is one of the few hormones that is involved in the regulation of circannual rhythms in animals. In mammals, it has been well established that the pars tuberalis is important in regulating seasonal reproduction and that melatonin plays a role in modifying clock gene expression in this tissue (Hanon et al. 2008, Yasuo et al. 2009). However, fish do not possess such an anatomically distinct pars tuberalis in the pituitary gland, and the involvement of melatonin in the fish reproductive cycle

Published by Bioscientifica Ltd. 
is only supported by a few studies. However, effects of melatonin have been described at the hypothalamic (Popek et al. 2005, Alvarado et al. 2015), pituitary (Khan \& Thomas 1996, Sébert et al. 2008) and gonadal (Chattoraj et al. 2005) levels.

The candidate function of melatonin as an input to the central circadian oscillator is supported by the observed coexpression of melatonin receptors with clock and per $1 b$ genes in some encephalic areas in rainbow trout (Mazurais et al. 2000) and goldfish (SánchezBretaño et al. 2015c).

In summary, pineal melatonin is the best known direct hormonal output of an endogenous clock that is entrained by LD cycles. This melatonin acts as a temporal messenger throughout the organism. It is likely that gut melatonin is also linked to putative peripheral clocks, which appear to be synchronised by different cues, such as feeding schedule.

\section{Orexin}

Orexins (orexin-A and orexin-B), which are also known as hypocretins, are neuropeptides that are derived from a single precursor polypeptide, pre-pro-orexin (Wong et al. 2011). The architecture of the orexin system (gene sequence, cell bodies, fibres and receptors) in the brain of fishes exhibits a general pattern that is common to all studied groups of vertebrates (Wong et al. 2011, López et al. 2014, Volkoff 2015a). The orexin system regulates neural activities that are responsible for coordinating daily functions across a range of taxa from fish to mammals, such as feeding behaviour, energy balance, locomotor activity and the sleep-wake cycle (reviewed in Matsuda et al. 2012, Gao \& Hermes 2015).

Studies in fish have indicated that there are interactions between orexin signalling and the circadian system, as previously reported in mammals (Gao \& Hermes 2015). Orexin fibres project to the pineal gland, the SCN (or its homologous in fish) and brain regions that are related to the regulation of sleep and arousal, such as the aminergic nuclei, raphe, locus coeruleus and histaminergic neurons (Wong et al. 2011, Volkoff 2012, López et al. 2014). Sleep-related experiments in zebrafish have shown that orexin-overexpressing larvae are hyperaroused and have dramatically reduced abilities to initiate and maintain rest at night (Prober et al. 2006); and orexin receptorknockout zebrafish exhibit short and fragmented sleep patterns (Yokogawa et al. 2007, Panula 2010). Experiments using this fish mutant have also indicated that orexin can modulate pineal melatonin production and sleep consolidation (Appelbaum et al. 2009). Furthermore, the number of synapses in orexin axons projecting into the pineal gland follows a daily rhythm in zebrafish larvae, which appears to be primarily driven by the circadian clock (Appelbaum et al. 2010). Consistent with these wake-promoting effects of orexin, increased activity of hypothalamic orexin neurons in zebrafish are associated with periods of increased locomotor activity (Naumann et al. 2010); and hypothalamic orexin expression in orange-spotted grouper (Epinephelus coioides; Yan et al. 2011), goldfish (Hoskins \& Volkoff 2012a) and Atlantic cod (Gadus morhua; Hoskins \& Volkoff 2012b) exhibits daily fluctuations, with the highest values occurring during the active phase.

Short-term periprandial changes in the expression of orexin have been observed in fishes. For example, orexin expression in the brain increases $1 \mathrm{~h}$ before the scheduled mealtime in Mexican blind cavefish (Astyanax fasciatus mexicanus; Wall \& Volkoff 2013); and hypothalamic pre-pro-orexin expression peaks around mealtime and decreases after feeding in Atlantic cod (Xu \& Volkoff 2007) and orange-spotted grouper (Yan et al. 2011). These data suggest that orexin may serve as a short-term hunger signal and may be linked to FAA. Supporting this, orexin treatment was found to re-establish daily locomotor activity rhythms in goldfish that had been maintained in the absence of zeitgebers (constant light and fasted conditions) suggesting the involvement of this peptide in the generation of FAA (Nisembaum et al. 2014a).

These daily variations in orexin expression may be related to the daily rhythms of clock genes; indeed, daily variations in the hypothalamic expression of orexin in goldfish have been related to clock genes oscillations (Hoskins \& Volkoff 2012a), and crosstalking between orexin signalling and the molecular clockwork has also been recently reported in this species (Nisembaum et al. 2014a). The finding that per genes in the hypothalamus and foregut are upregulated $3 \mathrm{~h}$ after an intracerebroventricular orexin injection indicates that this peptide may act as an input to these oscillators and regulate their daily functioning in goldfish (Nisembaum et al. 2014a). Moreover, in situ hybridisation studies in this teleost have revealed that some of the brain regions that exhibit day/night differences in per $1 b$ expression (Sánchez-Bretaño et al. 2015c) also possess orexin receptors (Facciolo et al. 2012). In this sense, recent data in mammals have suggested that the REV-ERBs may be involved in the repression of orexinergic gene expression (Feillet et al. 2015, Amador et al. 2016). However, to date,

Published by Bioscientifica Ltd 
it is unknown in fish if orexinergic genes may also be a clock target (Rev-erb target).

Together, these findings indicate that orexin not only is under the control of the molecular clock but also plays an important role in meal anticipation, acting as an input of the circadian system in fishes.

\section{Leptin}

Leptin is an anorexigenic peptide that regulates energy homeostasis in mammals and several fish species (reviewed in Gorissen \& Flik 2014, Londraville et al. 2014). Several different leptin isoforms have been found in fishes, the main one of which is leptin-a (Londraville et al. 2014). Leptin is predominantly expressed in the fish liver, which is an important energy-storing tissue, rather than in adipose tissue as in mammals (Gorissen \& Flik 2014, Londraville et al. 2014). Given its general role as an anorexigenic hormone, leptin expression is expected to increase after feeding and decrease after fasting, as reported in mammals, where plasma levels of this adipokine oscillate in a diurnal fashion, with increased values after food ingestion (Challet 2015, Kumar et al. 2015). In fishes, leptin expression also exhibits an acute and transient postprandial increase in the liver, with hepatic leptin-a expression generally increasing $6 \mathrm{~h}$ and $9 \mathrm{~h}$ after feeding in teleosts such as common carp (Cyprinus carpio; Huising et al. 2006), goldfish (Tinoco et al. 2012), Atlantic salmon (Moen \& Finn 2013), orange-spotted grouper (Zhang et al. 2013) and Mandarin fish (Siniperca chuatsi; Yuan et al. 2016).

Daily variations in the mRNA expression of leptin and the subsequent expected changes in hormone circulating levels in the blood will also be linked to the daily locomotor activity rhythm, as this is a well-known output of the circadian system. To our knowledge, the daily profile of leptin expression in fishes has only been studied in Atlantic salmon (Moen \& Finn 2013), goldfish (Tinoco et al. 2014) and zebrafish (Paredes et al. 2015) to date, in which the highest levels of hepatic expression occur at the end of the day. Thus, these species would be expected to experience an increase in blood leptin during the night, as this coincides with low nocturnal activity in goldfish and zebrafish. In mammals, the daily peak in circulating leptin also occurs during the fasting/sleeping period, with levels then declining before waking (reviewed in Patton \& Mistlberger 2013, Challet 2015, Kumar et al. 2015). All findings to date indicate that leptin facilitates a decreased appetite state during the inactive phase in animals, inhibiting the appearance of FAA.

One point that is still being debated is whether such a daily rhythm in leptin expression could be driven by endogenous oscillators. Under constant light conditions, leptin-a expression was rhythmic in goldfish that were fed at 10:00, but was not rhythmic in those that were fed at 22:00 or randomly, suggesting that feeding time alone cannot induce daily leptin rhythms in this species (Tinoco et al. 2014). These hepatic leptin-a rhythms also did not shift according to the feeding time in zebrafish under an LD cycle, indicating that light is probably the dominant synchroniser (Paredes et al. 2015). In addition, these daily leptin rhythms may also be regulated by rhythmic endogenous factors (hormones and foodderived metabolites), as described in mammals (Challet 2015, Kumar et al. 2015). In particular, the leptin rhythm in the goldfish liver is related to plasma glucose levels (Tinoco et al. 2014), with a postprandial glucose peak preceding the leptin peak, supporting the notion that leptin is induced by glucose in the hepatocytes of grass carp (Ctenopharyngodon idella; Lu et al. 2015).

A bidirectional link between the circadian system and leptin signalling has previously been described in mammals (Kettner et al. 2015). In adipose tissue, the rhythmic binding of the BMAL1/CLOCK heterodimer to the leptin promoter potentiates C/EBP $\alpha$-mediated leptin transcription during the early sleeping phase in mice (Mus musculus). However, there is currently no direct evidence that the peripheral clock regulates leptin transcription in fishes, although bmal1a and clock $1 a$ transcripts are rhythmic in the goldfish liver, exhibiting acrophases during the light phase (Sánchez-Bretaño 2016) that precede the peak in leptin expression (Tinoco et al. 2014). In mice, such regulation by the adipose clockwork is sufficient to drive diurnal oscillations of serum leptin, and the SCN pacemaker rhythmically potentiates the leptin-responsive neurons (Kettner et al. 2015). Therefore, this may explain the time-dependent effects of leptin on food intake in goldfish (Vivas et al. 2011). On the other hand, other studies on rodents have suggested that leptin can modulate circadian clocks, with in vitro experiments revealing that leptin leads to phase shifts in the SCN clock in rats (Rattus spp.; Prosser \& Bergeron 2003, Inyushkin et al. 2009). In vivo experiments show that leptin injection potentiates behavioural light-resetting in mice, which is accompanied by a higher induction of the clock genes Per1 and Per2 in the SCN (Mendoza et al. 2011). Moreover, it has been shown that genetically obese

Published by Bioscientifica Ltd 
mice (ob/ob, leptin deficiency; $d b / d b$, lacking the leptin receptor) exhibit disturbances in their peripheral clocks (Ando et al. 2011, Grosbellet et al. 2016). However, the modulation of circadian clocks by leptin in fishes remains unexplored.

Therefore, it seems that environmental (light and feeding) and endogenous (hormonal and metabolic) signals are involved in the daily leptin rhythms in fishes, and the leptin postprandial peak may provide postfeeding cues to the central and/or peripheral clocks.

\section{Ghrelin}

Ghrelin is a peptide that acts as a pleiotropic hormone in vertebrates. It has been implicated in the stimulation of growth hormone release from the pituitary, feeding and metabolism regulation and reproduction, among other functions, in both mammals (Al Massadi et al. 2015, Müller et al. 2015) and fishes (Kang et al. 2011, Shahjahan et al. 2014). As in other vertebrates, ghrelin in fishes is mainly synthesised in the intestinal tract, as well as in the brain (Kaiya et al. 2011, Eom et al. 2013, Zhou et al. 2014, Ji et al. 2015, Volkoff 2015a,b).

Over the last few years, several pieces of evidence have indicated a putative crosstalk between ghrelin and the circadian system in mammals. Plasma ghrelin levels display a daily rhythm that is related to the feeding cycle in many species (Cummings et al. 2001, Bodosi et al. 2004, Miura et al. 2004, Sanchez et al. 2004, Laermans et al. 2015), exhibiting a preprandial rise before each meal followed by a postprandial decrease in both diurnal and nocturnal mammals (Al Massadi et al. 2015, Jha et al. 2015, Müller et al. 2015). In vitro experiments in mice have demonstrated that ghrelin appears to work as an output of a FEO that is located in the oxyntic cells of the stomach (LeSauter et al. 2009, Laermans et al. 2015). Furthermore, FAA is significantly reduced in rodents that lack ghrelin receptors (LeSauter et al. 2009), and systemic administration of ghrelin activates a subset of specific neurons in the medial hypothalamus during FAA (Van der Plasse et al. 2013). Ghrelin also induces phase advances in the electrical activity of neurons in mouse SCN explants and promotes a phase advance in the rhythm of per2 expression, suggesting that it affects the SCN clockwork (Yannielli et al. 2007).

In goldfish, the ghrelin transcript exhibits a daily rhythm, with a nocturnal acrophase in the hypothalamus, pituitary gland and gastrointestinal tract (SánchezBretaño et al. 2015a), and plasma levels of acyl-ghrelin show periprandial variation (Blanco et al. 2016). Transient preprandial and postprandial changes in ghrelin mRNA levels have also been described in the brain of tilapia and zebrafish and in the telencephalon, intestinal bulb and hypothalamus of goldfish (Uniappan et al. 2004, Amole \& Unniappan 2009, Peddu et al. 2009, Blanco et al. 2016). These findings suggest that ghrelin could be a feedingor metabolic-related signal that synchronises FEOs and FAA in fishes (Fig. 1). This hypothesis is also supported by the fact that ghrelin modifies the locomotor activity (Matsuda et al. 2006, Yahashi et al. 2012), and a ghrelin antagonist prevents FAA (Nisembaum et al. 2014b) in goldfish.

The coexpression of ghrelin receptors and clock genes in both LEOs and FEOs supports the idea that ghrelin acts as an input signal of these clocks. In fishes, reverse transcription polymerase chain reaction (RT-PCR) has shown that ghrelin receptors are expressed in all brain regions (Chen et al. 2008, Small et al. 2009, Kaiya et al. 2010, Upton \& Riley 2013, Sánchez-Bretaño et al. 2015a, Zhang et al. 2016). Furthermore, in situ hybridisation has revealed that the transcripts of two ghrelin receptors (ghs-r1a and ghs-r2a) are expressed in several brain regions, including the hypothalamus and preoptic lobes in zebrafish (Cruz et al. 2010). ghs-r1a mRNA-positive cells occur in almost every area in goldfish, including the pallial and subpallial telencephalic regions, many hypothalamic nuclei (including the preoptic region and the anterior periventricular nucleus), the pineal gland, the habenular nuclei, the torus longitudinalis and the metencephalic valvula cerebelli (Sánchez-Bretaño et al. 2015a). Interestingly, the expression of several clock genes has also been described within these areas: per1b in goldfish (Sánchez-Bretaño et al. 2015c); per1b, per2, per3, clock, cry and bmal1 in zebrafish (Weger et al. 2013, Moore \& Whitmore 2014) and clock in rainbow trout (Mazurais et al. 2000). Some of these brain areas, such as the anterior periventricular nucleus (putatively homologous to the mammalian $\mathrm{SCN}$ ) and the pineal gland, are oscillators that allow the circadian rhythmicity to be entrained by the LD cycle (Idda et al. 2012, Moore $\&$ Whitmore 2014). These results support the putative role of ghrelin as a feeding- or metabolic-related signal that communicates to clocks that are synchronised by different cues (LD and feeding-fasting cycles).

The anatomical connection between ghrelin receptors and the circadian system may also be functional. In goldfish, an acute intraperitoneal injection of ghrelin induces the expression of orexin, per1a and per 3 in the hypothalamus (Nisembaum et al. 2014b).

Published by Bioscientifica Ltd. 
Furthermore, the actions of ghrelin are not restricted to central oscillators, but are also exerted on peripheral oscillators. In all studied fish species to date, ghrelin receptors are expressed in the oxyntic cells and/or the mucosal and submucosal intestinal cells and in the hepatocytes (Chen et al. 2008, Kaiya et al. 2009a,b, Eom et al. 2014, Cai et al. 2015, Sánchez-Bretaño et al. 2015a; Sánchez-Bretaño A, Blanco AM, Alonso-Gómez AL, Delgado MJ, Kah O \& Isorna E, unpublished observations), suggesting that ghrelin may also act as a local signal that entrains the stomach and/or gut oscillators. A direct effect of ghrelin on the gastrointestinal oscillator has not yet been demonstrated in vivo or in vitro in fishes. However, this has been suggested to occur in the liver of goldfish, in which an acute intraperitoneal injection of ghrelin upregulates the hepatic expression of the clock genes per1a, per2a and per3 $1 \mathrm{~h}$ after injection (Nisembaum et al. $2014 b$ ). Similarly, with in vitro hepatic cultures, ghrelin upregulates the expression of both the positive (bmal1a and clock1a) and negative (per1a, per1b, per2a and per3) elements of the main loop of clock genes, as well as the auxiliaryloop generev-erba (Sánchez-BretañoA, Blanco AM, Alonso-Gómez AL, Delgado MJ, Kah O \& Isorna E, unpublished observations; Fig. 2). This ghrelin-evoked gene induction is blocked by pretreatment with inhibitors of phospholipase C (PLC), protein kinase C (PKC) and, in some genes, protein kinase A (PKA), proving that ghrelin exerts its actions via the PLC-PKC and, to a lesser extent, adenylyl cyclase (AC)-PKA intracellular signalling pathways (Sánchez-Bretaño A, Blanco AM, AlonsoGómez AL, Delgado MJ, Kah O \& Isorna E, unpublished observations; Fig. 2).

In summary, all of the evidence to date supports a bidirectional link between the circadian clock and ghrelin signalling in fishes, as has been found in mammals. Current data demonstrate that ghrelin rhythms in the intestine, and likely the hypothalamus and pituitary gland, could be caused by the outputs of local oscillators. Furthermore, ghrelin may also participate in the regulation of FAA by either stimulating appetite or entraining endogenous clocks through the modification of clock gene expression.

\section{Glucocorticoids}

The hypothalamus-pituitary-interrenal (HPI) axis in fishes retains the classic organisation of the main neuroendocrine systems, being activated by stressful agents that trigger the release of stress hormones, glucocorticoids and catecholamines (Wendelaar Bonga 2011). Cortisol is the main glucocorticoid that is released into the teleost bloodstream from the interrenal (adrenal) cells, which are embedded in the head kidney region and are associated with catecholaminergic cells, lymphoid cells and the posterior cardinal veins (Barandica \& Tort 2008). During the onset of stress, cortisol induces several catabolic processes that provide energy to the different physiological actions that occur to restore homeostasis (Mommsen et al. 1999). A variety of biochemical, physiological and behavioural responses are also controlled by cortisol, such as energy metabolism, ionosmotic regulation, immunity and growth (reviewed in Mommsen et al. 1999, Ellis et al. 2012).

Cortisol, as melatonin, is considered one of the more robust hormonal outputs of the circadian system (Fig. 1). Under unstressed conditions, glucocorticoids exhibit a robust temporal secretion in mammals, with a circadian rhythmicity that overlaps an ultradian rhythmicity (Walker et al. 2010, Spiga et al. 2014). Cortisol (or corticosterone) secretion in mammals fluctuates with the LD cycle and is clearly related to the daily behavioural pattern, with a surge being seen at the onset of the activity phase each day. The sympathetic nervous system and the SCN control such daily variations via the hypothalamuspituitary-adrenal (HPA) axis (Haus 2007, Tonsfeldt \& Chappell 2012). However, increasing evidence has revealed that multiple components of the circadian system, and particularly the adrenal clock, are involved in the regulation of glucocorticoid rhythmicity in mammals (Son et al. 2011, Spiga et al. 2014).

Such a conserved pattern of circulating glucocorticoids is not evident in fishes, where a wide variety of daily patterns of plasma cortisol have been reported depending on the species, photoperiod, season and feeding and activity patterns. In relation to the LD cycle, the acrophase of daily cortisol rhythms occurs at the early photophase in Gulf killifish (Fundulus grandis; Garcia \& Meier 1973) and Mozambique tilapia (Oreochromis mossambicus; Nikaido et al. 2010), at the beginning of the scotophase in sea bass (Planas et al. 1990), tench (De Pedro et al. 1998) and sole (Solea senegalensis; López-Olmeda et al. 2013) and during the scotophase in brown trout (Salmo trutta; Pickering \& Pottinger 1983) and Japanese char (Salvelinus leucomaenis; Yamada et al. 2002). Two peaks in cortisol have been described in sea bass (Cerdá-Reverter et al. 1998) and Atlantic salmon smolts (Ebbesson et al. 2008). In addition to this range of daily profiles of circulating cortisol, there is also evidence for seasonal changes in http://joe.endocrinology-journals.org DOI: 10.1530/JOE-16-0330
(C) 2017 Society for Endocrinology Printed in Great Britain
Published by Bioscientifica Ltd 
some salmonids (Rance et al. 1982, Pickering \& Pottinger 1983, Thorpe et al. 1987), cyprinids (Kühn et al. 1986) and perciformes (Planas et al. 1990).

The feeding-fasting cycle and feeding time are powerful non-photic signals that may synchronise the daily cortisol rhythms in fishes. Indeed, periprandial cortisol changes have been observed in some teleosts, such as rainbow trout (Bry 1982, Hernández-Pérez et al. 2015), brown trout (Pickering \& Pottinger 1983), goldfish (Spieler \& Noeske 1984, Vera et al. 2007) and gilthead seabream (Sparus aurata; Montoya et al. 2010). However, this relationship between cortisol levels and feeding phase may be driven by the increase in locomotor activity rather than feeding time entrainment. The effect of fasting on the daily cortisol rhythm remains unclear, as starvation decreases the mean plasma cortisol level in channel catfish (Ictalurus punctatus; Small 2005), but increases the average cortisol levels (acting as a stressful event) without any modification to the daily cortisol rhythm in rainbow trout (Polakof et al. 2007, HernándezPérez et al. 2015). One interesting and almost unexplored question is whether these daily rhythmic variations in circulating cortisol in fishes are endogenous. To our knowledge, only one study has addressed this question, which indicated that the daily rhythm in plasma cortisol shows endogenous characteristics in the common dentex (Dentex dentex; Pavlidis et al. 1999).

The daily rhythms in the HPA axis have been widely reported in mammals (Kalsbeek et al. 2012, Spiga et al. 2014), whereas the existence of rhythms in the HPI axis components of fish has scarcely been investigated. A daily rhythm in circulating adrenocorticotropic hormone was demonstrated in goldfish (Singley \& Chavin 1976), and more recently, a rhythmic expression of genes encoding pro-opiomelanocortin (Gilchriest et al. 1998, López-Olmeda et al. 2013), corticotropin-releasing hormone (Crh; López-Olmeda et al. 2013) and the Crh receptor 1 (Azpeleta et al. 2012) has been demonstrated. Furthermore, the similar profiles that have been observed in crh expression and plasma cortisol in sole suggest that the daily cortisol rhythm may be a direct consequence of hypothalamic Crh production (López-Olmeda et al. 2013).

The recent discovery of a rhythmic expression of clock genes in the adrenal tissue of mammals strengthens the support for the existence of a functional circadian clock in this gland (Nicolaides et al. 2014, Spiga et al. 2014). However, the only report on the rhythmic expression of clock genes in fishes was in the interrenal tissue of the goldfish, where it was shown that the 24-h rhythmicity of per1a, per3 and cry3 is in antiphase to the clock1a rhythm, as would be expected for a functional core clock (Azpeleta et al. 2012). These data indicate that the interrenal tissue may act as a node within the circadian system network in fishes (Fig. 1).

Since the pioneering demonstration that the glucocorticoid hormone analogue dexamethasone can reset the circadian rhythms of clock gene expression in multiple peripheral cell types in the rat (Balsalobre et al. 2000), there has been increasing evidence that the circadian output of the adrenal gland plays a relevant role in synchronising the peripheral clocks in mammals (Dickmeis 2009, Kalsbeek et al. 2012, Schibler et al. 2015). So, does cortisol act as a resetting signal for the peripheral and/or central clocks in fishes? The few results currently available suggest that this is the case. Dexamethasone entrains bioluminescence rhythms in zebrafish and cavefish cell lines that have been transfected with zfper1b-luc (Cavallari et al. 2011). The molecular mechanism underlying this entrainment appears to be the glucocorticoid induction of per1, which has been reported to occur in the goldfish liver both in vivo and in vitro (Sánchez-Bretaño et al. 2016) and in cavefish cell lines (Cavallari et al. 2011). Similarly, in mammals, multiple glucocorticoid-response elements (GREs) are found in the per1 gene promoter sequence (Reddy et al. 2007). Moreover, in goldfish, dexamethasone represses the positive elements of the liver clock (bmal1a and clock1a) in culture (Sánchez-Bretaño et al. 2016), supporting a putative resetting function of glucocorticoids in fishes (Fig. 2). The widespread distribution of glucocorticoid receptors in fishes (Prunet et al. 2006) suggests that other peripheral clocks may also be entrained by cortisol.

It has been suggested that glucocorticoids may also act as a temporal signal in the broader context of circadian functional organisation, but it is currently unknown which physiological functions are regulated by putative glucocorticoid-sensitive clocks. In this sense, cortisol has been identified as a component of a systemic signalling pathway that is required for circadian cell cycle rhythmicity in zebrafish (Dickmeis et al. 2007) and appears to be involved in the regulation of the melatonergic system rhythmicity in rainbow trout (Benyassi et al. 2001, Ceinos et al. 2005), catfish (Clarias gariepinus; Yanthan \& Gupta 2007) and Mozambique tilapia (Nikaido et al. 2010).

Overall, these findings support the notion that cortisol acts as an input and maybe an output of the circadian system in fish. However, further investigation is required to demonstrate such an assertion and to explore the remaining unresolved questions, such as the nature

Published by Bioscientifica Ltd 
of the inputs that synchronise the interrenal clock and cortisol rhythms.

\section{Communication among oscillators: hormones as temporal internal messengers}

Based on all the data presented here, we propose a hypothetical model of entrainment of the molecular clockwork, in which the 24-h clock gene oscillations are sustained via light and hormonal inputs (Fig. 2). The LD cycle reaches the core clock via the light-evoked induction of cry 1 and per2 in zebrafish (via the functional E- and D-boxes and the thyrotroph embryonic factor (Tef) transcription factor; Tamai et al. 2007, Vatine et al. 2009, 2011). Based on the observed acute induced changes in gene expression, we also propose additional mechanisms whereby hormones such as cortisol and ghrelin can entrain the molecular clocks. As discussed previously, in the goldfish liver, cortisol induces per1a and per $1 b$ and represses bmal1 $a$ and clock, whereas ghrelin induces a variety of clock genes via the PLC-PKC pathway and, to a lesser extent, the AC-PKA pathway (SánchezBretaño et al. 2016; Sánchez-Bretaño A, Blanco AM, Alonso-Gómez AL, Delgado MJ, Kah O \& Isorna E, unpublished observations; Fig. 2).

However, the bidirectional link between the daily rhythms of clock genes in endocrine tissues and hormonal rhythms still needs to be deeply studied in fishes. In particular, it is important to know the answers to two questions: are clock gene oscillations in endocrine tissues linked to hormonal overt rhythms and are hormonalinduced changes in clock gene transcripts sufficient to induce the entrainment of the molecular core?

The answer to the first question seems clear for melatonin rhythms. Clock gene oscillations in the fish pineal gland are directly driven by LD cycles, and these oscillations, in turn, control the expression of the clockcontrolled gene aanat2, which codes the key enzyme for melatonin synthesis (Appelbaum et al. 2006, Falcón et al. 2009). However, as stated previously, hepatic leptin expression rhythms are not always linked to clock genes daily rhythms in the liver of goldfish (Tinoco et al. 2014). Furthermore, although feeding time drives clock genes oscillations in the sea bream liver (Vera et al. 2013), it does not control the rhythms of enzymes that are involved in lipid metabolism (Paredes et al. 2014); and in zebrafish, lipid metabolism is linked to the LD cycle and independent of feeding time (Paredes et al. 2015). Thus, the physiological functions of peripheral oscillators in fishes remain unclear. The use of in silico analysis to search for clock-controlled genes (i.e. genes whose promoters hold putative E-box, D-box and RORE elements) would be very useful for further investigating this issue.

With regard to the second question, glucocorticoids have a clear role as internal messengers in mammals (Albrecht 2012, Kalsbeek etal.2012, Schibler etal.2015) and this also appears to be the case for fishes. Dexamethasone entrains bioluminescence rhythms in zebrafish and cavefish cell lines that have been transfected with zfper1bluc (Cavallari et al. 2011), as well as clock gene rhythms in the goldfish liver in vitro (Sánchez-Bretaño 2016). As discussed previously, glucocorticoids probably repress the positive elements and induce the negative elements of the core clock (Sánchez-Bretaño et al. 2016; Fig. 2). However, whether the acute changes in clock gene expression that are induced by orexin and ghrelin in vivo (Nisembaum et al. $2014 a, b)$ and by ghrelin in vitro (Sánchez-Bretaño A, Blanco AM, Alonso-Gómez AL, Delgado MJ, Kah O \& Isorna $\mathrm{E}$, unpublished observations) can reset the clock remains to be explored. Finally, considering the variety of signals that are involved in regulating clock genes, it is likely that other less-studied hormones also influence the fish clockwork. In particular, the family of per genes appears to be the target for different cues in fishes, including light, orexin, ghrelin and glucocorticoids (Vatine et al. 2009, Nisembaum et al. 2014a,b, Sánchez-Bretaño et al. 2015; Sánchez-Bretaño A, Blanco AM, Alonso-Gómez AL, Delgado MJ, Kah O \& Isorna E, unpublished observations; Fig. 2) and so may be involved in shifting the molecular clock. Similarly, the light-resetting of the SCN clock and the adjustment of peripheral oscillators by glucocorticoids are also mediated by per genes in mammals (Albrecht 2012, Schibler et al. 2015).

Our hypothetical model of endogenous clock entrainment agrees with the non-hierarchical model of fish circadian organisation, in which the variety of oscillators can be entrained independently by different hormonal cues and according to the specific sensitivity of each tissue to these signals. Recently, it has been proposed that peripheral oscillators are also entrained by temperature via transient receptor potential channels, which are also involved in light synchronisation (Poletini et al. 2015), but the functional entrainment has not been demonstrated to date. These findings support the concept of a more flexible organisation of the circadian system in fishes than previously thought. It could be hypothesised that vertebrate ancestors would have had a variety of clocks that were widely distributed and probably independently synchronised to different

Published by Bioscientifica Ltd 
factors (light, temperature and food), which has since evolved into a very hierarchical system in mammals and perhaps an intermediate state in fishes. As previously suggested (Idda et al. 2012), a versatile circadian system in fishes is expected considering the large number of teleost species and the wide variety of habitats they inhabit.

\section{Declaration of interest}

The authors declare that there is no conflict of interest that could be perceived as prejudicing the impartiality of this review.

\section{Funding}

This research was supported by the Spanish Ministry of Economy and Competitiveness project (MINECO; AGL2013-46448-C3-2-R, AGL201674857-(3-2-R).

\section{Acknowledgments}

The authors thank all past and present PhD students of the UCM 'Fish Neuroendocrinology Research Group' for their contributions.

\section{References}

Al Massadi O, López M, Fernø J, Diéguez C \& Nogueiras R 2015 What is the real relevance of endogenous ghrelin? Peptides 70 1-6. (doi:10.1016/j.peptides.2015.04.027)

Albrecht U 2012 Timing to perfection: the biology of central and peripheral circadian clocks. Neuron 74 246-260. (doi:10.1016/j. neuron.2012.04.006)

Alvarado MV, Carrillo M \& Felip A 2015 Melatonin-induced changes in kiss/gnrh gene expression patterns in the brain of male sea bass during spermatogenesis. Comparative Biochemistry and Physiology: Part A Molecular and Integrative Physiology 185 69-79. (doi:10.1016/j. cbpa.2015.03.010)

Amador A, Wang Y, Banerjee S, Kameneka TM, Solt LA \& Burris TP 2016 Pharmacological and genetic modulation of REV-ERB activity and expression affects orexigenic gene expression. PLOS ONE 11 e0151014. (doi:10.1371/journal.pone.0151014)

Amole N \& Unniappan S 2009 Fasting induces preproghrelin mRNA expression in the brain and gut of zebrafish, Danio rerio. General and Comparative Endocrinology 161 133-137. (doi:10.1016/j. ygcen.2008.11.002)

Ando H, Kumazaki M, Motosugi Y, Ushijima K, Maekawa T, Ishikawa E \& Fujimura A 2011 Impairment of peripheral circadian clocks precedes metabolic abnormalities in ob/ob mice. Endocrinology 152 1347-1354. (doi:10.1210/en.2010-1068)

Appelbaum L, Vallone D, Anzulovich A, Ziv L, Tom M, Foulkes NS \& Gothilf Y 2006 Zebrafish arylalkylamine-N-acetyltranferase genestargets for regulation of the circadian clock. Journal of Molecular Endocrinology 36 337-347. (doi:10.1677/jme.1.01893)

Appelbaum L, Wang G, Maro GS, Mori R, Tovin A, Marin W, Yokogawa T, Kawakami K, Smith SJ, Gothilf Y, et al. 2009 Sleep-wake regulation and hypocretin-melatonin interaction in zebrafish. PNAS $\mathbf{1 0 6}$ 21942-21947. (doi:10.1073/pnas.906637106)

Appelbaum L, Wang G, Yokogawa T, Skariah GM, Smith SJ, Mourrain P \& Mignot E 2010 Circadian and homeostatic regulation of structural synaptic plasticity in hypocretin neurons. Neuron 68 87-98. (doi:10.1016/j.neuron.2010.09.006)

Aranda A, Madrid JA \& Sánchez-Vázquez FJ 2001 Influence of light on feeding anticipatory activity in goldfish. Journal of Biological Rhythms 16 50-57. (doi:10.1177/074873040101600106)

Azpeleta C, Sánchez-Bretaño A, Isorna E, Nisembaum LG, Velarde E, De Pedro N, Alonso-Gómez AL \& Delgado MJ 2012 Understanding the circadian system as a net of clocks: daily expression of clock genes in the hypothalamus pituitary interrenal axis in Carassius auratus. In Advances en Endocrinología Comparada Vol VI, pp 37-40. Eds MJ Delgado, AL Alonso-Gómez, N De Pedro \& E Isorna. Madrid, Spain: Servicio de Publicaciones de la Universidad Complutense de Madrid.

Balsalobre A, Brown SA, Marcacci L, Tronche F, Kellendock C, Reichardt HM, Schütz G \& Schibler U 2000 Resetting of circadian time in peripheral tissues by glucocorticoid signalling. Science $\mathbf{2 8 9}$ 2344-2347. (doi:10.1126/science.289.5488.2344)

Barandica LM \& Tort L 2008 Neuroendocrinología e inmunología de la respuesta al estrés en peces. Revista de la Academia Colombiana de Ciencias 32 267-284.

Bayarri MJ, Rol De Lama MA, Madrid JA \& Sánchez-Vázquez FJ 2003 Both pineal and lateral eyes are needed to sustain daily circulating melatonin rhythms in the sea bass. Brain Research 969 175-182. (doi:10.1016/S0006-8993(03)02297-2)

Benyassi A, Schwartz C, Ducouret B \& Falcón J 2001 Glucocorticoid receptors and serotonin $\mathrm{N}$-acetyltransferase activity in the fish pineal organ. Neuroreport 12 889-892. (doi:10.1097/00001756-20010417000004)

Besseau L, Benyassi A, Moller M, Coon SL, Weller JL, Boeuf G, Klein DC \& Falcón J 2006 Melatonin pathway: breaking the 'high-at-night' rule in trout retina. Experimental Eye Research 82 620-627. (doi:10.1016/j. exer.2005.08.025)

Blanco AM, Gómez-Boronat M, Redondo I, Valenciano AI \& Delgado MJ 2016 Periprandial changes and effects of short- and long-term fasting on ghrelin, GOAT, and ghrelin receptors in goldfish (Carassius auratus). Journal of Comparative Physiology B 186 727-738. (doi:10.1007/s00360-016-0986-0)

Blanco-Vives B, Aliaga-Guerrero M, Cañavate JP, García-Mateos G, Martín-Robles AJ, Herrera-Pérez P, Muñoz-Cueto JA \& SánchezVázquez FJ 2012 Metamorphosis induces a light-dependent switch in Senegalese sole (Solea senegalensis) from diurnal to nocturnal behavior. Journal of Biological Rhythms 27 135-144. (doi:10.1177/0748730411435303)

Bodosi B, Gardi J, Hajdu I, Szentirmai E, Obal F Jr \& Krueger JM 2004 Rhythms of ghrelin, leptin, and sleep in rats: effects of the normal diurnal cycle, restricted feeding, and sleep deprivation. American Journal of Physiology: Regulatory, Integrative and Comparative Physiology 287 R1071-R1079. (doi:10.1152/ajpregu.00294.2004)

Bolliet V, Ali MA, Lapointe FJ \& Falcón J 1996 Rhythmic melatonin secretion in different teleost species: an in vitro study. Journal of Comparative Physiology B 165 677-683. (doi:10.1007/BF00301136)

Bromage N, Duston J, Randall C, Brook A, Thrush M, Carrillo M \& Zanuy S 1990 Photoperiodic control of teleost reproduction. Progress in Clinical and Biological Research 342 620-626.

Bry C 1982 Daily variations in plasma cortisol levels of individual female rainbow trout Salmo gairdneri: evidence for a post-feeding peak in well-adapted fish. General and Comparative Endocrinology 48 462-468. (doi:10.1016/0016-6480(82)90181-2)

Bubenik GA \& Pang SF 1997 Melatonin levels in the gastrointestinal tissues of fish, amphibians, and a reptile. General and Comparative Endocrinology 106 415-419. (doi:10.1006/gcen.1997.6889)

Buhr ED, Yoo SH \& Takahashi JS 2010 Temperature as a universal resetting cue for mammalian circadian oscillators. Science 330 379-385. (doi:10.1126/science.1195262)

Cahill GM 1996 Circadian regulation of melatonin production in cultured zebrafish pineal and retina. Brain Research 708 177-181. (doi:10.1016/0006-8993(95)01365-2) http://joe.endocrinology-journals.org

DOI: $10.1530 /$ JOE-16-0330 (c) 2017 Society for Endocrinology Printed in Great Britain 
Cahill GM 2002 Clock mechanisms in zebrafish. Cell and Tissue Research 309 27-34. (doi:10.1007/s00441-002-0570-7)

Cai WJ, Yuan XC, Yuan YC, Xie SQ, Gong Y, Su H \& Qiao Y 2015 Sequence, genomic organization and expression of ghrelin receptor in grass carp, Ctenopharyngodon idellus. Comparative Biochemistry and Physiology: Part A Molecular and Integrative Physiology 179 54-61. (doi:10.1016/j.cbpa.2014.09.009)

Cassone VM, Warren WS, Brooks DS \& Lu J 1993 Melatonin, the pineal gland, and circadian rhythms. Journal of Biological Rhythms $\mathbf{8}$ (Supplement) S73-S81.

Cavallari N, Frigato E, Vallone D, Fröhlich N, López-Olmeda JF, Foà A, Berti R, Sánchez-Vázquez FJ, Bertolucci C \& Foulkes NS 2011 A blind circadian clock in cavefish reveals that opsins mediate peripheral clock photoreception. PLoS Biology 9 e1001142. (doi:10.1371/journal. pbio.1001142)

Cazaméa-Catalan D, Besseau L, Falcón J \& Magnanou E 2014 The timing of Timezyme diversification in vertebrates. PLOS ONE 9 e112380. (doi:10.1371/journal.pone.0112380)

Ceinos RM, Rábade S, Soengas JL \& Míguez JM 2005 Indoleamines and 5 -methoxyindoles in trout pineal organ in vivo: daily changes and influence of photoperiod. General and Comparative Endocrinology 144 67-77. (doi:10.1016/j.ygcen.2005.04.010)

Cerdá-Reverter JM, Zanuy S, Carrillo M \& Madrid JA 1998 Timecourse studies on plasma glucose, insulin, and cortisol in sea bass (Dicentrarchus labrax) held under different photoperiodic regimes. Physiology and Behavior 64 245-250. (doi:10.1016/s00319384(98)00048-1)

Cermakian N, Whitmore D, Foulkes NS \& Sassone-Corsi P 2000 Asynchronous oscillations of two zebrafish CLOCK partners reveal differential clock control and function. PNAS 97 4339-4344. (doi:10.1073/pnas.97.8.4339)

Challet E 2015 Keeping circadian time with hormones. Diabetes, Obesity and Metabolism 17 76-83. (doi:10.1111/dom.12516)

Chattoraj A, Bhattacharya S, Basu D, Bhattacharya S, Bhattacharya S \& Maitra SK 2005 Melatonin accelerates maturation inducing hormone (MIH): induced oocyte maturation in carps. General and Comparative Endocrinology 140 145-155. (doi:10.1016/j.ygcen.2004.10.013)

Chen T, Tang Z, Yan A, Li W \& Lin H 2008 Molecular cloning and mRNA expression analysis of two GH secretagogue receptor transcripts in orange-spotted grouper (Epinephelus coioides). Journal of Endocrinology 199 253-265. (doi:10.1677/JOE-08-0325)

Choi JY, Kim NN, Choi YJ, Park MS \& Choi CY 2016 Differential daily rhythms of melatonin in the pineal gland and gut of goldfish Carassius auratus in response to light. Biological Rhythm Research 47 145-161. (doi:10.1080/09291016.2015.1094964)

Costa LS, Serrano I, Sánchez-Vázquez FJ \& López-Olmeda JF 2016 Circadian rhythms of clock gene expression in Nile tilapia (Oreochromis niloticus) central and peripheral tissues: influence of different lighting and feeding conditions. Journal of Comparative Physiology B 186 775-785. (doi:10.1007/s00360-016-0989-x)

Cruz SA, Tseng YC, Kaiya H \& Hwang PP 2010 Ghrelin affects carbohydrate-glycogen metabolism via insulin inhibition and glucagon stimulation in the zebrafish (Danio rerio) brain. Comparative Biochemistry Physiology: Part A Molecular and Integrative Physiology 156 190-200. (doi:10.1016/j.cbpa.2010.01.019)

Cummings DE, Purnell JQ, Frayo RS, Schmidova K, Wisse BE \& Weigle DS 2001 A preprandial rise in plasma ghrelin levels suggests a role in meal initiation in humans. Diabetes 50 1714-1719. (doi:10.2337/ diabetes.50.8.1714)

Davie A, Minghetti M \& Migaud H 2009 Seasonal variations in clockgene expression in Atlantic salmon (Salmo salar). Chronobiology International 26 379-395. (doi:10.1080/07420520902820947)

Davies WI, Tamai TK, Zheng L, Fu JK, Rihel J, Foster RG, Whitmore D \& Hankins MW 2015 An extended family of novel vertebrate photopigments is widely expressed and displays a diversity of function. Genome Research 25 1666-1679. (doi:10.1101/ gr.189886.115)

De Pedro N, Delgado MJ, Pinillos ML, Alonso-Gómez AL \& Alonso-Bedate M 1998 Daily rhythms in NAT activity, cortisol, glucose, glycogen and catecholamines in tench (Tinca tinca (L.)). Polish Archives of Hydrobiology 45 321-329.

Dickmeis T 2009 Glucocorticoids and the circadian clock. Journal of Endocrinology 200 3-22. (doi:10.1677/JOE-08-0415)

Dickmeis T, Lahiri K, Nica G, Vallone D, Santoriello C, Neumann CJ, Hammerschmidt M \& Foulkes NS 2007 Glucocorticoids play a key role in circadian cell cycle rhythms. PLoS Biology 5 e78. (doi:10.1371/ journal.pbio.0050078)

Ebbesson LOE, Björnsson BT, Ekström P \& Stefansson SO 2008 Daily endocrine profiles in parr and smolt in Atlantic salmon. Comparative Biochemistry Physiology: Part A Molecular and Integrative Physiology 151 698-704. (doi:10.1016/j.cbpa.2008.08.017)

Ekström P \& Vanecek J 1992 Localization of 2-[125I]iodomelatonin binding sites in the brain of the Atlantic salmon, Salmo salar L. Neuroendocrinology 55 529-537. (doi:10.1159/000126166)

Elbaz I, Foulkes NS, Gothilf Y \& Appelbaum L 2013 Circadian clocks, rhythmic synaptic plasticity and the sleep-wake cycle in zebrafish. Frontiers in Neural Circuits 7 9. (doi:10.3389/fncir.2013.00009)

Ellis T, Yildiz HY, López-Olmeda J, Spedicato MT, Tort L, Øverli Ø \& Martins C 2012 Cortisol and finfish welfare. Fish Physiology and Biochemistry 38 163-188. (doi:10.1007/s10695-011-9568-y)

Eom J, Hong M, Cone RD \& Song Y 2013 Zebrafish ghrelin is expressed in pancreatic endocrine cells and regulated by metabolic state. Biochemical and Biophysical Research Communications 439 115-120. (doi:10.1016/j.bbrc.2013.08.017)

Eom J, Hong A, Kang YH, Yoo HJ, Chang EJ, Kang SW, Yoon SY, Kim SY \& Song Y 2014 Molecular cloning, regulation, and functional analysis of two GHS-R genes in zebrafish. Experimental Cell Research 326 10-21. (doi:10.1016/j.yexcr.2014.06.002)

Facciolo RM, Crudo M, Zizza M, Giusi G \& Canonaco M $2012 \alpha$ GABA(A) subunit-orexin receptor interactions activate learning/motivational pathways in the goldfish. Behavioral Brain Research 234 349-356. (doi:10.1016/j.bbr.2012.07.013)

Falcón J, Besseau L, Sauzet S \& Boeuf G 2007 Melatonin effects on the hypothalamo-pituitary axis in fish. Trends in Endocrinology and Metabolism 18 81-88. (doi:10.1016/j.tem.2007.01.002)

Falcón J, Besseau L, Fuentès M, Sauzet S, Magnanou E \& Boeuf G 2009 Structural and functional evolution of the pineal melatonin system in vertebrates. Annals of the New York Academy of Sciences 1163 101-111. (doi:10.1111/j.1749-6632.2009.04435.x)

Falcón J, Migaud H, Muñoz-Cueto JA \& Carrillo M 2010 Current knowledge on the melatonin system in teleost fish. General and Comparative Endocrinology 165 469-482. (doi:10.1016/j. ygcen.2009.04.026)

Feillet CA, Bainier C, Mateo M, Blancas-Velázquez A, Salaberry NL, Ripperger JA, Albrecht U \& Mendoza J 2015 Rev-erb $\alpha$ modulates the hypothalamic orexinergic system to influence pleasurable feeding behaviour in mice. Addiction Biology. [in press] (doi:10.1111/ adb.12339)

Feliciano A, Vivas Y, de Pedro N, Delgado MJ, Velarde E \& Isorna E 2011 Feeding time synchronizes clock gene rhythmic expression in brain and liver of goldfish (Carassius auratus). Journal of Biological Rhythms 26 24-33. (doi:10.1177/0748730410388600)

Fernández-Durán B, Ruibal C, Polakof S, Ceinos RM, Soengas JL \& Míguez JM 2007 Evidence for arylalkylamine N-acetyltransferase (AANAT2) expression in rainbow trout peripheral tissues with emphasis in the gastrointestinal tract. General and Comparative Endocrinology 152 289-294. (doi:10.1016/j.ygcen.2006.12.008)

Gandhi AV, Mosser EA, Oikonomou G \& Prober DA 2015 Melatonin is required for the circadian regulation of sleep. Neuron 85 1193-1199. (doi:10.1016/j.neuron.2015.02.016) http://joe.endocrinology-journals.org

DOI: $10.1530 / \mathrm{JOE}-16-0330$
๑) 2017 Society for Endocrinology Printed in Great Britain 
Gao X-B \& Hermes G 2015 Neural plasticity in hypocretin neurons: the basis of hypocretinergic regulation of physiological and behavioral functions in animals. Frontiers in Systems Neuroscience 9142. (doi:10.3389/fnsys.2015.00142)

García LE \& Meier AH 1973 Daily rhythms in concentration of plasma cortisol in male and female Gulf Killifish, Fundulus grandis. Biological Bulletin 144 471-479. (doi:10.2307/1540301)

Gilchriest BJ, Tipping DR, Levy A \& Baker BI 1998 Diurnal changes in the expression of genes encoding for arginine vasotocin and pituitary pro-opiomelanocortin in the rainbow trout (Oncorhynchus mykiss): correlation with changes in plasma hormones. Journal of Neuroendocrinology 10 937-943. (doi:10.1046/j.13652826.1998.00283.x)

Gorissen M \& Flik G 2014 Leptin in teleostean fish, towards the origins of leptin physiology. Journal of Chemical Neuroanatomy 61-62 200-206. (doi:10.1016/j.jchemneu.2014.06.005)

Grosbellet E, Dumont S, Schuster-Klein C, Guardiola-Lemaitre B, Pevet P, Criscuolo F \& Challet E 2016 Circadian phenotyping of obese and diabetic $d b / d b$ mice. Biochimie 124 198-206. (doi:10.1016/j. biochi.2015.06.029)

Guillaumond F, Dardente H, Giguere V \& Cermakian N 2005 Differential control of Bmal1 circadian transcription by REV-ERB and ROR nuclear receptors. Journal of Biological Rhythms 20 391-403. (doi:10.1177/0748730405277232)

Hang CY, Kitahashi T \& Parhar IS 2016 Neuronal organization of deep brain opsin photoreceptors in adult teleosts. Frontiers in Neuroanatomy 10 48. (doi:10.3389/fnana.2016.00048)

Hanon EA, Lincoln GA, Fustin JM, Dardente H, Masson-Pévet M, Morgan PJ \& Hazlerigg DG 2008 Ancestral TSH mechanism signals summer in a photoperiodic mammal. Current Biology 18 1147-1152. (doi:10.1016/j.cub.2008.06.076)

Hastings M, O’Neill JS \& Maywood ES 2007 Circadian clocks: regulators of endocrine and metabolic rhythms. Journal of Endocrinology 195 187-198. (doi:10.1677/JOE-07-0378)

Haus E 2007 Chronobiology in the endocrine system. Advances in Drug Delivery Reviews 59 985-1014. (doi:10.1016/j.addr.2007.01.001)

Hernández-Pérez J, Míguez JM, Librán-Pérez M, Otero-Rodiño C, Nahderi F, Soengas JL \& López-Patiño MA 2015 Daily rhythms in activity mRNA abundance of enzymes involved in glucose and lipid metabolism in liver of rainbow trout, Oncorhynchus mykiss. Influence of light and food availability. Chronobiology International 32 1391-1408. (doi:10.3109/07420528.2015.1100633)

Herrero MJ, Martínez FJ, Míguez JM \& Madrid JA 2007 Response of plasma and gastrointestinal melatonin, plasma cortisol and activity rhythms of European sea bass (Dicentrarchus labrax) to dietary supplementation with tryptophan and melatonin. Journal of Comparative Physiology B 177 319-326. (doi:10.1007/s00360-0060131-6)

Hoskins LJ \& Volkoff H $2012 a$ Daily patterns of mRNA expression of two core circadian regulatory proteins, Clock2 and Per1, and two appetite-regulating peptides, OX and NPY, in goldfish (Carassius auratus). Comparative Biochemistry and Physiology: Part A Molecular and Integrative Physiology 163 127-136. (doi:10.1016/j.cbpa.2012.05.197)

Hoskins LJ \& Volkoff H $2012 b$ The comparative endocrinology of feeding in fish: insights and challenges. General and Comparative Endocrinology 176 327-335. (doi:10.1016/j.ygcen.2011.12.025)

Huang TS, Ruoff P \& Fjelldal PG 2010 Effect of continuous light on daily levels of plasma melatonin and cortisol and expression of clock genes in pineal gland, brain, and liver in Atlantic salmon postsmolts. Chronobiology International 27 1715-1734. (doi:10.3109/07420528.20 10.521272)

Huising MO, Geven EJ, Kruiswijk CP, Nabuurs SB, Stolte EH, Spanings FAT, Verburg-van Kemenade BML \& Flik G 2006 Increased leptin expression in common Carp (Cyprinus carpio) after food intake but not after fasting or feeding to satiation. Endocrinology 147 5786-5797. (doi:10.1210/en.2006-0824)
Idda ML, Bertolucci C, Vallone D, Gothilf Y, Sánchez-Vázquez FJ \& Foulkes NS 2012 Circadian clocks: lessons from fish. Progress in Brain Research 199 41-57. (doi:10.1016/B978-0-444-59427-3.00003-4)

Iigo M, Furukawa KHA, Ohtani-Kaneko R, Hara M, Suzuki T, Tabata M \& Aida K 1997a Ocular melatonin rhythms in the goldfish, Carassius auratus. Journal of Biological Rhythms 12 182-192. (doi:10.1177/07487 3049701200209)

Iigo M, Sánchez-Vázquez FJ, Madrid JA, Zamora S \& Tabata M 1997 b Unusual responses to light and darkness of ocular melatonin in European sea bass. Neuroreport 8 1631-1635. (doi:10.1097/00001756199705060-00015)

Ikegami T, Azuma K, Nakamura M, Suzuki N, Hattori A \& Ando H 2008 Diurnal expressions of four subtypes of melatonin receptor genes in the optic tectum and retina of goldfish. Comparative Biochemistry and Physiology: Part A Molecular and Integrative Physiology 152 219-224. (doi:10.1016/j.cbpa.2008.09.030)

Inyushkin AN, Bhumbra GS \& Dyball RE 2009 Leptin modulates spike coding in the rat suprachiasmatic nucleus. Journal of Neuroendocrinology 21 705-714. (doi:10.1111/j.13652826.2009.01889.x)

Jha PK, Challet E \& Kalsbeek A 2015 Circadian rhythms in glucose and lipid metabolism in nocturnal and diurnal mammals. Molecular and Cellular Endocrinology 418 74-88. (doi:10.1016/j.mce.2015.01.024)

Ji W, Ping HC, Wei KJ, Zhang GR, Shi ZC, Yang RB, Zou GW \& Wang WM 2015 Ghrelin, neuropeptide Y (NPY) and cholecystokinin (CCK) in blunt snout bream (Megalobrama amblycephala): cDNA cloning, tissue distribution and mRNA expression changes responding to fasting and refeeding. General and Comparative Endocrinology 223 108-119. (doi:10.1016/j.ygcen.2015.08.009)

Kaiya H, Mori T, Miyazato M \& Kangawa K 2009a Ghrelin receptor (GHS-R)-like receptor and its genomic organisation in rainbow trout, Oncorhynchus mykiss. Comparative Biochemistry and Physiology: Part A Molecular and Integrative Physiology 153 438-450. (doi:10.1016/j. cbpa.2009.04.612)

Kaiya H, Riley LG, Janzen W, Hirano T, Grau EG, Miyazato M \& kangawa K $2009 b$ Identification and genomic sequence of a ghrelin receptor(GHS-R)-like receptor in the Mozambique tilapia, Oreochromis mossambicus. Zoological Science 26 330-337. (doi:10.2108/zsj.26.330)

Kaiya H, Miura T, Matsuda K, Miyazato M \& Kangawa K 2010 Two functional growth hormone secretagogue receptor (ghrelin receptor) type $1 \mathrm{a}$ and $2 \mathrm{a}$ in goldfish, Carassius auratus. Molecular and Cellular Endocrinology 327 25-39. (doi:10.1016/j.mce.2010.06.004)

Kaiya H, Miyazato M \& Kangawa K 2011 Recent advances in the phylogenetic study of ghrelin. Peptides 32 2155-2174. (doi:10.1016/j. peptides.2011.04.027)

Kalsbeek A, van der Spek R, Lei J, Endert E, Buijs RM \& Fliers E 2012 Circadian rhythms in the hypothalamo-pituitary-adrenal (HPA) axis. Molecular and Cellular Endocrinology 349 20-29. (doi:10.1016/j. mce.2011.06.042)

Kang KS, Yahashi S \& Matsuda K 2011 Central and peripheral effects of ghrelin on energy balance, food intake and lipid metabolism in teleost fish. Peptides 32 2242-2247. (doi:10.1016/j. peptides.2011.05.006)

Kettner NM, Mayo SA, Hua J, Lee C, Moore DD \& Fu L 2015 Circadian dysfunction induces leptin resistance in mice. Cell Metabolism 22 448-459. (doi:10.1016/j.cmet.2015.06.005)

Kezuka H, Iigo M, Furukawa K, Aida K \& Hanyu I 1992 effects of photoperiod, pinealectomy and ophthalmectomy on circulating melatonin rhythms in the goldfish, Carassius auratus. Zoological Science 9 1047-1053.

Khan IA \& Thomas P 1996 Melatonin influences gonadotropin II secretion in the Atlantic Croaker (Micropogonias undulatus). General and Comparative Endocrinology 104 231-242. (doi:10.1006/ gcen.1996.0166)

Klein DC, Ganguly S, Coon S, Weller JL, Obsil T, Hickman A \& Dyda F 2002 14-3-3 Proteins and photoneuroendocrine transduction: role

Published by Bioscientifica Ltd. 
in controlling the daily rhythm in melatonin. Biochemical Society Transactions 30 365-373. (doi:10.1042/bst0300365)

Kornmann B, Schaad O, Reinke H, Saini C \& Schibler U 2007 Regulation of circadian gene expression in liver by systemic signals and hepatocyte oscillators. Cold Spring Harbor Symposia on Quantitative Biology 72 319-330. (doi:10.1101/sqb.2007.72.041)

Kühn ER, Corneille S \& Ollevier F 1986 Circadian variations in plasma osmolality, electrolytes, glucose, and cortisol in carp (Cyprinus carpio). General and Comparative Endocrinology 61 459-468. (doi:10.1016/00166480(86)90234-0)

Kumar Jha P, Challet E \& Kalsbeek A 2015 Circadian rhythms in glucose and lipid metabolism in nocturnal and diurnal mammals. Molecular and Cellular Endocrinology 418 74-88. (doi:10.1016/j.mce.2015.01.024)

Laermans J, Vancleef L, Tack J \& Depoortere I 2015 Role of the clock gene Bmal1 and the gastric ghrelin-secreting cell in the circadian regulation of the ghrelin-GOAT system. Science Reports $\mathbf{5} 16748$. (doi:10.1038/srep16748)

LeSauter J, Hoque N, Weintraub M, Pfaff DW \& Silver R 2009 Stomach ghrelin-secreting cells as food-entrainable circadian clocks. PNAS 106 13582-13587. (doi:10.1073/pnas.0906426106)

Lin XW, Blum ID \& Storch KF 2015 Clocks within the master gland: hypophyseal rhythms and their physiological significance. Journal of Biological Rhythms 30 263-276. (doi:10.1177/0748730415580881)

Londraville RL, Macotela Y, Duff RJ, Easterling MR, Liu Q \& Crespi EJ 2014 Comparative endocrinology of leptin: assessing function in a phylogenetic context. General and Comparative Endocrinology 203 146-157. (doi:10.1016/j.ygcen.2014.02.002)

López JM, Sanz-Morello B \& González A 2014 Organization of the orexin/ hypocretin system in the brain of two basal actinopterygian fishes, the cladistians Polypterus senegalus and Erpetoichthys calabaricus. Peptides 61 23-37. (doi:10.1016/j.peptides.2014.08.011)

López-Olmeda JF, Madrid JA \& Sánchez-Vázquez FJ 2006 Melatonin effects on food intake and activity rhythms in two fish species with different activity patterns: diurnal (goldfish) and nocturnal (tench). Comparative Biochemistry and Physiology: Part A Molecular and Integrative Physiology 144 180-187. (doi:10.1016/j.cbpa.2006.02.031)

López-Olmeda JF, Tartaglione EV, de la Iglesia HO \& Sánchez-Vázquez FJ 2010 Feeding entrainment of food-anticipatory activity and per1 expression in the brain and liver of zebrafish under different lighting and feeding conditions. Chronobiology International 27 1380-1400. (doi:10.3109/07420528.2010.501926)

López-Olmeda B, Blanco-Vives I, Pujante M, Wunderink YS, Mancera JM \& Sánchez-Vázquez FJ 2013 Daily rhythms in the hypothalamuspituitary-interrenal axis and acute stress responses in a teleost flatfish, Solea senegalensis. Chronobiology International 30 530-539. (doi:10.310 9/07420528.2012.754448)

Lu RH, Zhou Y, Yuan XC, Liang XF, Fang L, Bai XL, Wang M \& Zhao YH 2015 Effects of glucose, insulin and triiodothyroxine on leptin and leptin receptor expression and the effects of leptin on activities of enzymes related to glucose metabolism in grass carp (Ctenopharyngodon idella) hepatocytes. Fish Physiology and Biochemistry 41 981-989. (doi:10.1007/s10695-015-0063-8)

Martín-Robles ÁJ, Whitmore D, Sánchez-Vázquez FJ, Pendón C \& Muñoz-Cueto JA 2012 Cloning, tissue expression pattern and daily rhythms of Period1, Period2, and Clock transcripts in the flatfish Senegalese sole, Solea senegalensis. Journal of Comparative Physiology B 182 673-685. (doi:10.1007/s00360-012-0653-z)

Martinez-Chavez CC, Al-Khamees S, Campos-Mendoza A, Penman DJ \& Migaud H 2008 Clock controlled endogenous melatonin rhythms in Nile tilapia (Oreochromis niloticus niloticus) and African catfish (Clarias gariepinus). Chronobiology International 25 31-49. (doi:10.1080/07420520801917547)

Martins RS, Gomez A, Zanuy S, Carrillo M \& Canário AV 2015 Photoperiodic Modulation of circadian clock and reproductive axis gene expression in the pre-pubertal European sea bass brain. PLoS ONE 10 e0144158. (doi:10.1371/journal.pone.0144158)
Matsuda K, Miura T, Kaiya H, Maruyama K, Uchiyama M, Kangawa K \& Shioda S 2006 Stimulatory effect of n-octanoylated ghrelin on locomotor activity in the goldfish, Carassius auratus. Peptides $\mathbf{2 7}$ 1335-1340. (doi:10.1016/j.peptides.2005.10.011)

Matsuda K, Azuma M \& Kang KS 2012 Orexin system in teleost fish. Vitamins and Hormones 89 341-361. (doi:10.1016/b978-0-12-3946232.00018-4)

Mazurais D, Le Dréan G, Brierley I, Anglade I, Bromage N, Williams LM $\&$ Kah O 2000 Expression of clock gene in the brain of rainbow trout: comparison with the distribution of melatonin receptors. Journal of Comparative Neurology 422 612-620. (doi:10.1002/10969861(20000710)422:4<612::AID-CNE9>3.0.CO;2-Y)

McStay E, Migaud H, Vera LM, Sánchez-Vázquez FJ \& Davie A 2014 Comparative study of pineal clock gene and AANAT2 expression in relation to melatonin synthesis in Atlantic salmon (Salmo salar) and European seabass (Dicentrarchus labrax). Comparative Biochemistry and Physiology: Part A Molecular and Integrative Physiology 169 77-89. (doi:10.1016/j.cbpa.2013.12.011)

Menaker M, Moreira LF \& Tosini G 1997 Evolution of circadian organization in vertebrates. Brazilian Journal of Medical and Biological Research 30 305-313. (doi:10.1590/S0100-879X1997000300003)

Mendoza J, Lopez-Lopez C, Revel FG, Jeanneau K, Delerue F, Prinssen E, Challet E, Moreau JL \& Grundschober C 2011 Dimorphic effects of leptin on the circadian and hypocretinergic systems of mice. Journal of Neuroendocrinology 23 28-38. (doi:10.1111/j.13652826.2010.02072.x)

Migaud H, Taylor JF, Taranger GL, Davie A, Cerdá-Reverter JM, Carrillo M Hansen T \& Bromage NB 2006 A comparative ex vivo and in vivo study of day and night perception in teleosts species using the melatonin rhythm. Journal of Pineal Research 41 42-52. (doi:10.1111/ j.1600-079X.2006.00330.x)

Migaud H, Davie A, Martinez Chavez CC \& Al-Khamees S 2007 Evidence for differential photic regulation of pineal melatonin synthesis in teleosts. Journal of Pineal Research 43 327-335. (doi:10.1111/j.1600079X.2007.00480.x)

Migaud H, Davie A \& Taylor JF 2010 Current knowledge on the photoneuroendocrine regulation of reproduction in temperate fish species. Journal of Fish Biology 76 27-68. (doi:10.1111/j.10958649.2009.02500.x)

Miura H, Tsuchiya N, Sasaki I, Kikuchi M, Kojima M, Kangawa K, Hasegawa Y \& Ohnami Y 2004 Changes in plasma ghrelin and growth hormone concentrations in mature holstein cows and three-month-old calves. Journal of Animal Science 82 1329-1333. (doi: $10.2527 / 2004.8251329 x$ )

Moen AG \& Finn RN 2013 Short-term, but not long-term feed restriction causes differential expression of leptins in Atlantic salmon. General and Comparative Endocrinology 183 83-88. (doi:10.1016/j. ygcen.2012.09.027)

Mommsen TP, Vijayan MM \& Moon TW 1999 Cortisol in teleosts: dynamics, mechanisms of action, and metabolic regulation. Reviews in Fish Biology and Fisheries 9 211-268. (doi:10.102 3/A:1008924418720)

Montoya A, López-Olmeda JF, Garayzar ABS \& Sánchez-Vázquez FJ 2010 Synchronization of daily rhythms of locomotor activity and plasma glucose, cortisol and thyroid hormones to feeding in Gilthead seabream (Sparus aurata) under a light-dark cycle. Physiology and Behavior 101 101-107. (doi:10.1016/j.physbeh.2010.04.019)

Moore HA \& Whitmore D 2014 Circadian rhythmicity and light sensitivity of the zebrafish brain. PLOS ONE 9 e86176. (doi:10.1371/ journal.pone.0086176)

Mukherjee S \& Maitra SK 2015 Effects of starvation, re-feeding and timing of food supply on daily rhythm features of gut melatonin in carp (Catla catla). Chronobiology International 32 1264-1277. (doi:10.3109/07420528.2015.1087020)

Mukherjee S, Moniruzzaman M \& Maitra SK 2014 Daily and seasonal profiles of gut melatonin and their temporal relationship with pineal

Published by Bioscientifica Ltd. 
and serum melatonin in carp Catla catla under natural photo-therma conditions. Biological Rhythm Research 45 301-315. (doi:10.1080/0929 1016.2013.817139)

Müller TD, Nogueiras R, Andermann ML, Andrews ZB, Anker SD, Argente J, Batterham RL, Benoit SC, Bowers CY, Broglio F, et al. 2015 Ghrelin. Molecular Metabolism 4 437-460. (doi:10.1016/j. molmet.2015.03.005)

Muñoz-Pérez JL, López-Patiño MA, Álvarez-Otero R, Gesto M, Soengas JL \& Míguez JM 2016 Characterization of melatonin synthesis in the gastrointestinal tract of rainbow trout (Oncorhynchus mykiss): distribution, relation with serotonin, daily rhythms and photoperiod regulation. Journal of Comparative Physiology B186 471-484. (doi:10.1007/s00360-016-0966-4)

Nakane Y, Ikegami K, Iigo M, Ono H, Takeda K, Takahashi D, Uesaka M, Kimijima M, Hashimoto R, Arai N, et al. 2013 The saccus vasculosus of fish is a sensor of seasonal changes in day length. Nature Communications 4 2108. (doi:10.1038/ncomms3108)

Naumann EA, Kampff AR, Prober DA, Schier AF \& Engert F 2010 Monitoring neural activity with bioluminescence during natural behavior. Nature Neuroscience 13 513-520. (doi:10.1038/nn.2518)

Nicolaides NC, Charmandari E, Chrousos GP \& Kino T 2014 Circadian endocrine rhythms: the hypothalamic-pituitary-adrenal axis and its actions. Annual New York Academic Sciences 1318 71-80. (doi:10.1111/ nyas.12464)

Nikaido Y, Aluru N, McGuire A, Park Y-J, Vijayan MM \& Takemura A 2010 Effect of cortisol on melatonin production by the pineal organ of tilapia, Oreochromis mossambicus. Comparative Biochemistry Physiology: Part A Molecular and Integrative Physiology 155 84-90. (doi:10.1016/j. cbpa.2009.10.006)

Nisembaum LG, Velarde E, Tinoco AB, Azpeleta C, de Pedro N, Alonso-Gómez AL, Delgado MJ \& Isorna E 2012 Light-dark cycle and feeding time differentially entrains the gut molecular clock of the goldfish (Carassius auratus). Chronobiology International 29 665-673. (doi:10.3109/07420528.2012.686947)

Nisembaum LG, De Pedro N, Delgado MJ, Sánchez-Bretaño A \& Isorna E $2014 a$ Orexin as an input of circadian system in goldfish: Effects on clock gene expression and locomotor activity rhythms. Peptides $\mathbf{5 2}$ 29-37. (doi:10.1016/j.peptides.2013.11.014)

Nisembaum LG, de Pedro N, Delgado MJ \& Isorna E $2014 b$ Crosstalking between the "gut-brain" hormone ghrelin and the circadian system in the goldfish. Effects on clock gene expression and food anticipatory activity. General and Comparative Endocrinology 205 287-295. (doi:10.1016/j.ygcen.2014.03.016)

Nishiwaki-Ohkawa T \& Yoshimura T 2016 Molecular basis for regulating seasonal reproduction in vertebrates. Journal of Endocrinology 229 R117-R127. (doi:10.1530/JOE-16-0066)

Noche RR, Lu PN, Goldstein-Kral L, Glasgow E \& Liang JO 2011 Circadian rhythms in the pineal organ persist in zebrafish larvae that lack ventral brain. BioMed Central Neuroscience 12 7. (doi:10.1186/1471-2202-12-7)

Panula P 2010 Hypocretin/orexin in fish physiology with emphasis on zebrafish. Acta Physiologica 198 381-386. (doi:10.1111/j.17481716.2009.02038.x)

Paredes JF, Vera LM, Martinez-Lopez FJ, Navarro I \& Sánchez Vázquez FJ 2014 Circadian rhythms of gene expression of lipid metabolism in Gilthead Sea bream liver: synchronisation to light and feeding time. Chronobiology International 31 613-626. (doi:10.3109/07420528.2014. 881837)

Paredes JF, López-Olmeda JF, Martínez FJ \& Sánchez-Vázquez FJ 2015 Daily rhythms of lipid metabolic gene expression in zebra fish liver: response to light/dark and feeding cycles. Chronobiology International 32 1438-1448. (doi:10.3109/07420528.2015.1104327)

Park YJ, Park JG, Kim SJ, Lee YD, Saydur Rahman M \& Takemura A 2006 Melatonin receptor of a reef fish with lunar-related rhythmicity: cloning and daily variations. Journal of Pineal Research 41 166-174. (doi:10.1111/j.1600-079X.2006.00350.x)
Park JG, Park YJ, Sugama N, Kim SJ \& Takemura A 2007 Molecular cloning and daily variations of the Period gene in a reef fish Siganus guttatus. Journal of Comparative Physiology A 193 403-411. (doi:10.1007/s00359-006-0194-6)

Patiño MA, Rodríguez-Illamola A, Conde-Sieira M, Soengas JL \& Míguez JM 2011 Daily rhythmic expression patterns of clock1a, bmal1, and per1 genes in retina and hypothalamus of the rainbow trout, Oncorhynchus mykiss. Chronobiology International 28 381-389. (doi:10.3109/07420528.2011.566398)

Patton DF \& Mistlberger RE 2013 Circadian adaptations to meal timing; neurondocrine mechanisms. Frontiers in Neuroscience 7 1-14. (doi:10.3389/fnins.2013.00185)

Pavlidis M, Greenwood L, Paalavuo M, Mölsä H \& Laitinen JT 1999. The effect of photoperiod on diel rhythms in serum melatonin, cortisol, glucose, and electrolytes in the common dentex, Dentex dentex. General and Comparative Endocrinology 113 240-250. (doi:10.1006/ gcen.1998.7190)

Peddu SC, Breves JP, Kaiya H, Gordon Grau E \& Riley LG Jr 2009 Pre- and postprandial effects on ghrelin signaling in the brain and on the GH/IGF-I axis in the Mozambique tilapia (Oreochromis mossambicus). General and Comparative Endocrinology 161 412-418. (doi:10.1016/j. ygcen.2009.02.008)

Pevet P \& Challet E 2011 Melatonin: both master clock output and internal time-giver in the circadian clocks network. Journal of Physiology Paris 105 170-182. (doi:10.1016/j.jphysparis.2011.07.001)

Pickering AD \& Pottinger TG 1983 Seasonal and diel changes in plasma cortisol levels of the brown trout, Salmo trutta L. General and Comparative Endocrinology 49 232-239. (doi:10.1016/00166480(83)90139-9)

Planas J, Gutiérrez J, Fernández J, Carrillo M \& Canals P 1990 Annual and daily variations of plasma cortisol in sea bass, Dicentrarchus labrax L. Aquaculture 91 171-178. (doi:10.1016/00448486(90)90186-Q)

Polakof S, Ceinos RM, Fernández-Durán B, Míguez JM, \& Soengas JL 2007 Daily changes in parameters of energy metabolism in brain of rainbow trout: dependence of feeding. Comparative Biochemistry and Physiology: Part A Molecular and Integrative Physiology 146 265-273. (doi:10.1016/j.cbpa.2006.10.026)

Poletini MO, Moraes MN, Ramos BC, Jerônimo R \& Castrucci AM 2015 TRP channels: a missing bond in the entrainment mechanism of peripheral clocks throughout evolution. Temperature 2 522-534. (doi:10.1080/23328940.2015.1115803)

Popek W, Uszczek-Trojnar E, Drng-Kozak E, Fortuna-Wroska D \& Epler P 2005 Effect of the pineal gland and melatonin on dopamine release from perifused hypothalamus of mature female carp during spawning and winter regression. Acta Ichthyologica et Piscatoria 35 65-71. (doi:10.3750/AIP2005.35.2.01)

Prober DA, Rihel J, Onah AA, Sung RJ \& Schier AF 2006 Hypocretin/ orexin overexpression induces an insomnia-like phenotype in zebrafish. Journal of Neuroscience 26 13400-13410. (doi:10.1523/ JNEUROSCI.4332-06.2006)

Prosser RA \& Bergeron HE 2003 Leptin phase-advances the rat suprachiasmatic circadian clock in vitro. Neuroscience Letters 336 139-142. (doi:10.1016/S0304-3940(02)01234-X)

Prunet P, Sturm A \& Milla S 2006 Multiple corticosteroid receptors in fish: From old ideas to new concepts. General and Comparative Endocrinology 147 17-23. (doi:10.1016/j.ygcen.2006.01.015)

Rance TA, Baker BI \& Webley G 1982 Variations in plasma cortisol concentrations over a 24-hour period in the rainbow trout Salmo gairdneri. General and Comparative Endocrinology 48 269-274. (doi:10.1016/0016-6480(82)90026-0)

Reddy AB, Maywood ES, Karp NA, King VM, Inoue Y, González FJ, Lilley KS, Kyriacou CP \& Hastings MH 2007 Glucocorticoid signalling synchronizes the liver circadian transcriptome. Hepatology $\mathbf{4 5}$ 1478-1488. (doi:10.1002/hep.21571) http://joe.endocrinology-journals.org

DOI: $10.1530 / J O E-16-0330$
() 2017 Society for Endocrinology Printed in Great Britain 
Reppert SM \& Weaver DR 2002 Coordination of circadian timing in mammals. Nature 418 935-941. (doi:10.1038/nature00965)

Reppert SM, Weaver DR \& Godson C 1996 Melatonin receptors step into the light: cloning and classification of subtypes. Trends in Pharmacological Science 17 100-102. (doi:10.1016/01656147(96)10005-5)

Ribelayga, C, Wang Y \& Mangel SC 2004 A circadian clock in the fish retina regulates dopamine release via activation of melatonin receptors. Journal of Physiology 554 467-482. (doi:10.1113/ jphysiol.2003.053710)

Sánchez J, Oliver P, Picó C \& Palou A 2004 Diurnal rhythms of leptin and ghrelin in the systemic circulation and in the gastric mucosa are related to food intake in rats. Pflügers Archiv 448 500-506. (doi:10.1007/s00424-004-1283-4)

Sánchez-Bretaño A 2016 Interacción entre el sistema endocrino y los osciladores circadianos en el carpín (Carassius auratus): regulación de genes reloj en relojes centrales y periféricos por péptidos de origen gastrointestinal y por glucocorticoides. PhD Thesis. University Complutense of Madrid.

Sánchez-Bretaño A, Blanco AM, Unniappan S, Kah O, Gueguen MM, Bertucci JI, Alonso-Gómez ÁL, Valenciano AI, Isorna E \& Delgado MJ 2015 a In situ localization and rhythmic expression of ghrelin and ghs-r1 ghrelin receptor in the brain and gastrointestinal tract of goldfish (Carassius auratus). PLoS ONE 10 e0141043. (doi:10.1371/ journal.pone.0141043)

Sánchez-Bretaño A, Alonso-Gómez ÁL, Delgado MJ \& Isorna E 2015b The liver of goldfish as a component of the circadian system: Integrating a network of signals. General and Comparative Endocrinology 221 213-216. (doi:10.1016/j.ygcen.2015.05.001)

Sánchez-Bretaño A, Gueguen MM, Cano-Nicolau J, Kah O, Alonso-Gómez ÁL, Delgado MJ \& Isorna E 2015c Anatomical distribution and daily profile of gper $1 b$ gene expression in brain and peripheral structures of goldfish (Carassius auratus). Chronobiology International 32 889-902. (doi:10.3109/07420528.2015.1049615)

Sánchez-Bretaño A, Callejo M, Montero M, Alonso-Gómez ÁL, Delgado MJ \& Isorna E 2016 Performing a hepatic timing signal: glucocorticoids induce gper $1 a$ and gper $1 b$ expression and repress gclock1a and gbmal1a in the liver of goldfish. Journal of Comparative Physiology B 186 73-82. (doi:10.1007/s00360-015-0936-2)

Sauzet S, Besseau L, Herrera Perez P, Covès D, Chatain B, Peyric E, Boeuf G, Muñoz-Cueto JA \& Falcón J 2008 Cloning and retinal expression of melatonin receptors in the European sea bass, Dicentrarchus labrax. General and Comparative Endocrinology 157 186-195. (doi:10.1016/j.ygcen.2008.04.008)

Schibler U, Gotic I, Saini C, Gos P, Curie T, Emmenegger Y, Sinturel F, Gosselin P, Gerber A, Fleury-Olela F, et al. 2015 Clock-talk: interactions between central and peripheral circadian oscillators in mammals. Cold Spring Harbor Symposia on Quantitative Biology 80 223-232. (doi:10.1101/sqb.2015.80.027490)

Sébert ME, Legros C, Weltzien FA, Malpaux B, Chemineau P \& Dufour S 2008 Melatonin activates brain dopaminergic systems in the eel with an inhibitory impact on reproductive function. Journal of Neuroendocrinology 20 917-929. (doi:10.1111/j.13652826.2008.01744.x)

Shahjahan M, Kitahashi T \& Parhar IS 2014 Central pathways integrating metabolism and reproduction in teleosts. Frontiers in Endocrinology 5 36. (doi:10.3389/fendo.2014.00036)

Singley JA \& Chavin W 1976 The diel rhythm of circulating ACTH titer in the goldfish (Carassius auratus L.). Comparative Biochemistry and Physiology: Part A Molecular and Integrative Physiology 53 291-293. (doi:10.1016/S0300-9629(76)80038-2)

Small BC 2005 Effect of fasting on nychthemeral concentrations of plasma growth hormone (GH), insulin-like growth factor I (IGF-I), and cortisol in channel catfish (Ictalurus punctatus). Comparative Biochemistry and Physiology: Part B Biochemistry and Molecular Biology 142 217-223. (doi:10.1016/j.cbpb.2005.07.008)
Small BC, Quiniou SM \& Kaiya H 2009 Sequence, genomic organization and expression of two channel catfish, Ictalurus punctatus, ghrelin receptors. Comparative Biochemistry and Physiology: Part A Molecular and Integrative Physiology 154 451-464. (doi:10.1016/j. cbpa.2009.07.027)

Son GH, Chung S \& Kim K 2011 The adrenal peripheral clock: glucocorticoid and the circadian timing system. Frontiers in Neuroendocrinology 32 451-465. (doi:10.1016/j.yfrne.2011.07.003)

Spieler RE \& Noeske TA 1984 Effects of photoperiod and feeding schedule on diel variations of locomotor activity, cortisol, and thyroxine in goldfish. Transactions of the American Fisheries Society 113 528-39. (doi:10.1577/1548-8659(1984)113<528:EOPAFS >2.0.CO;2)

Spiga F, Walker JJ, Terry JR \& Lightman SL 2014 HPA axis-rhythms. Comprehensive Physiology 4 1273-1298. (doi:10.1002/cphy.c140003)

Stephan FK 2002 The 'other' circadian system: food as a zeitgeber. Journal of Biological Rhythms 17 284-292. (doi:10.1177/0748730021 29002591)

Stokkan KA, Yamazaki S, Tei H, Sakaki Y \& Menaker M 2001 Entrainment of the circadian clock in the liver by feeding. Science $291490-493$. (doi:10.1126/science.291.5503.490)

Takeuchi Y, Hada N, Imamura S, Hur SP, Bouchekioua S \& Takemura A 2015 Existence of a photoinducible phase for ovarian development and photoperiod-related alteration of clock gene expression in a damselfish. Comparative Biochemistry and Physiology: Part A Molecular and Integrative Physiology 188 32-39. (doi:10.1016/j.cbpa.2015.06.010)

Tamai TK, Carr AJ \& Whitmore D 2005 Zebrafish circadian clocks: cells that see light. Biochemical Society Transactions 33 962-966. (doi:10.1042/BST0330962)

Tamai TK, Young LC \& Whitmore D 2007 Light signaling to the zebrafish circadian clock by Cryptochrome 1a. PNAS 104 14712-14717. (doi:10.1073/pnas.0704588104)

Thorpe JE, McConway MG, Miles MS \& Muir JS 1987 Diel and seasonal changes in resting plasma cortisol levels in juvenile Atlantic salmon, Salmo salar L. General and Comparative Endocrinology 65 19-22. (doi:10.1016/0016-6480(87)90217-6)

Tinoco AB, Nisembaum LG, Isorna E, Delgado MJ \& De Pedro N 2012 Leptins and leptin receptor expression in the goldfish (Carassius auratus). Regulation by food intake and fasting/overfeeding conditions. Peptides 34 329-335. (doi:10.1016/j.peptides.2012.02.001)

Tinoco AB, Nisembaum LG, De Pedro N, Delgado MJ \& Isorna E 2014 Leptin expression is rhythmic in brain and liver of goldfish (Carassius auratus). Role of feeding time. General and Comparative Endocrinology 204 239-247. (doi:10.1016/j.ygcen.2014.06.006)

Tonsfeldt KJ \& Chappell PE 2012 Clocks on top: the role of the circadian clock in the hypothalamic and pituitary regulation of endocrine physiology. Molecular Cellular Endocrinology 349 3-12. (doi:10.1016/j. mce.2011.07.003)

Unniappan S, Canosa LF \& Peter RE 2004 Orexigenic actions of ghrelin in goldfish: feeding-induced changes in brain and gut mRNA expression and serum levels, and responses to central and peripheral injections. Neuroendocrinology 79 100-108. (doi:10.1159/000076634)

Upton KR \& Riley LG 2013 Acute stress inhibits food intake and alters ghrelin signaling in the brain of tilapia (Oreochromis mossambicus). Domestic Animal Endocrinology 44 157-164. (doi:10.1016/j. domaniend.2012.10.001)

Vakkuri O, Rintamäki H \& Leppäluoto J 1985 Plasma and tissue concentrations of melatonin after midnight light exposure and pinealectomy in the pigeon. Journal of Endocrinology 105 263-268. (doi:10.1677/joe.0.1050263)

Van der Plasse G, Merkestein M, Luijendijk MC, van der Roest M, Westenberg HG, Mulder AB \& Adan RA 2013 Food cues and ghrelin recruit the same neuronal circuitry. International Journal of Obesity $\mathbf{3 7}$ 1012-1019. (doi:10.1038/ijo.2012.174)

Vatine G, Vallone D, Appelbaum L, Mracek P, Ben-Moshe Z, Lahiri K, Gothilf Y \& Foulkes NS 2009 Light directs zebrafish period2 
expression via conserved D and E boxes. PLoS Biology $7 \mathrm{e} 1000223$. (doi:10.1371/journal.pbio.1000223)

Vatine G, Vallone D, Gothilf Y \& Foulkes NS 2011 It's time to swim! Zebrafish and the circadian clock. FEBS Letters 585 1485-1494. (doi:10.1016/j.febslet.2011.04.007)

Velarde E, Haque R, Iuvone PM, Azpeleta C, Alonso-Gómez AL \& Delgado MJ 2009 Circadian clock genes of goldfish, Carassius auratus: cDNA cloning and rhythmic expression of period and cryptochrome transcripts in retina, liver, and gut. Journal of Biological Rhythms $\mathbf{2 4}$ 104-113. (doi:10.1177/0748730408329901)

Velarde E, Cerdá Reverter JM, Alonso-Gómez AL, Sánchez E, Isorna E \& Delgado MJ 2010 Melatonin-synthesizing enzymes in pineal, retina, liver and gut in the goldfish (Carassius auratus): mRNA expression pattern and regulation of daily rhythms by lighting conditions. Chronobiology International 27 1178-1201. (doi:10.3109/07420528.2010.496911)

Vera LM, De Pedro N, Gómez-Milán E, Delgado MJ, Sánchez-Muros MJ, Madrid JA \& Sánchez-Vázquez FJ 2007 Feeding entrainment of locomotor activity rhythms, digestive enzymes and neuroendocrine factors in goldfish. Physiology and Behavior 90 518-524. (doi:10.1016/j.physbeh.2006.10.017)

Vera LM, Negrini P, Zagatti C, Frigato E, Sánchez-Vázquez FJ \& Bertolucci C 2013 Light and feeding entrainment of the molecular circadian clock in a marine teleost (Sparus aurata). Chronobiology International 30 649-661. (doi:10.3109/07420528.2013.775143)

Vivas Y, Azpeleta C, Feliciano A, Velarde E, Isorna E, Delgado MJ \& de Pedro N 2011 Time-dependent effects of leptin on food intake and locomotor activity in goldfish. Peptides 32 989-995. (doi:10.1016/j. peptides.2011.01.028)

Volkoff H 2012 Sleep and orexins in nonmammalian vertebrates. Vitamins and Hormones 89 315-339. (doi:10.1016/b978-0-12-3946232.00017-2)

Volkoff H 2015a Cloning, tissue distribution and effects of fasting on mRNA expression levels of leptin and ghrelin in red-bellied piranha (Pygocentrus nattereri). General and Comparative Endocrinology 217-218 20-27. (doi:10.1016/j.ygcen.2015.05.004)

Volkoff $\mathrm{H} 2015 b$ Cloning and tissue distribution of appetite-regulating peptides in pirapitinga (Piaractus brachypomus). Journal of Animal Physiology and Animal Nutrition 99 987-1001. (doi:10.1111/jpn.12318)

Walker JJ, Ferrry JR \& Lightman SL 2010 Origin of ultradian pulsatility in the hypothalamic-pituitary-adrenal axis. Proceeding of the Royal Society B 277 1627-1633. (doi:10.1098/rspb.2009.2148)

Wall A \& Volkoff H 2013 Effects of fasting and feeding on the brain mRNA expressions of orexin, tyrosine hydroxylase (TH), PYY and CCK in the Mexican blind cavefish (Astyanax fasciatus mexicanus). General and Comparative Endocrinology 183 44-52. (doi:10.1016/j. ygcen.2012.12.011)

Weger M, Weger BD, Diotel N, Rastegar S, Hirota T, Kay SA, Strähle U \& Dickmeis T 2013 Real-time in vivo monitoring of circadian E-box enhancer activity: a robust and sensitive zebrafish reporter line for developmental, chemical and neural biology of the circadian clock. Developmental Biology 380 259-273. (doi:10.1016/j.ydbio.2013.04.035)

Wendelaar-Bonga SE 2011 Hormonal responses to stress. In Encyclopaedia of Fish Physiology, pp 1515-1523. Ed. PF Anthony. San Diego, CA, USA: Academic Press.

Wong KK, Ng SY, Lee LT, Ng HK \& Chow BK 2011 Orexins and their receptors from fish to mammals: a comparative approach. General and Comparative Endocrinology 171 124-130. (doi:10.1016/j ygcen.2011.01.001)

Yahashi S, Kang KS, Kaiya H \& Matsuda K 2012 GHRP-6 mimics ghrelin-induced stimulation of food intake and suppression of locomotor activity in goldfish. Peptides 34 324-328. (doi:10.1016/j. peptides.2012.01.025)

Yamada H, Satoh R-I, Ogoh M, Takaji K, Fujimoto Y, Hakuba T, Chiba H, Kambegawa A \& Iwata M 2002 Circadian changes in serum concentrations of steroids in Japanese char Salvelinus leucomaenis at the stage of final maturation. Zoological Science 19 891-898. (doi:10.2108/zsj.19.891)

Yan A, Zhang L, Tang Z, Zhang Y, Qin C, Li B, Li W \& Lin H 2011 Orange-spotted grouper (Epinephelus coioides) orexin: molecular cloning, tissue expression, ontogeny, daily rhythm and regulation of NPY gene expression. Peptides 32 1363-1370. (doi:10.1016/j. peptides.2011.05.004)

Yannielli PC, Molyneux PC, Harrington ME \& Golombek DA 2007 Ghrelin effects on the circadian system of mice. Journal of Neuroscience 27 2890-2895. (doi:10.1523/JNEUROSCI.3913-06.2007)

Yanthan L \& Gupta BB 2007 In vitro effects of steroid hormones on arylalkylamine $\mathrm{N}$-acetyltransferase (AA-NAT) activity in the pineal of fish, Clarias gariepinus (Burchell, 1822) during different phases of breeding cycle. Indian Journal of Experimental Biology 45 676-682.

Yasuo S, Yoshimura T, Ebihara S \& Korf HW 2009 Melatonin transmits photoperiodic signals through the MT1 melatonin receptor. Journal of Neuroscience 29 2885-2889. (doi:10.1523/JNEUROSCI.0145-09.2009)

Yokogawa T, Marin W, Faraco J, Pezeron G, Appelbaum L, Zhang J, Rosa F, Mourrain P \& Mignot E 2007 Characterization of sleep in zebrafish and insomnia in hypocretin receptor mutants. PLoS Biology 5 e277. (doi:10.1371/journal.pbio.0050277)

Yuan X, Li A, Liang XF, Huang W, Song Y, He S, Cai W \& Tao YX 2016 Leptin expression in mandarin fish Siniperca chuatsi (Basilewsky): regulation by postprandial and short-term fasting treatment. Comparative Biochemistry and Physiology: Part A Molecular and Integrative Physiology 194 8-18. (doi:10.1016/j.cbpa.2016.01.014)

Xu M \& Volkoff H 2007 Molecular characterization of prepro-orexin in Atlantic cod (Gadus morhua): cloning, localization, developmental profile and role in food intake regulation. Molecular and Cellular Endocrinology 271 28-37. (doi:10.1016/j.mce.2007.03.003)

Zaunreiter M, Brandstätter R \& Goldschmid A 1998 Evidence for an endogenous clock in the retina of rainbow trout: I. Retinomotor movements, dopamine and melatonin. Neuroreport 9 1205-1209. (doi:10.1097/00001756-199804200-00045)

Zhang H, Chen H, Zhang Y, Li S, Lu D, Zhang H, Meng Z, Liu X \& Lin H 2013 Molecular cloning, characterization and expression profiles of multiple leptin genes and a leptin receptor gene in orange-spotted grouper (Epinephelus coioides). General and Comparative Endocrinology 181 295-305. (doi:10.1016/j.ygcen.2012.09.008)

Zhang J, Ma W, He Y, Wu J, Dawar FU, Ren F, Zhao X \& Mei J 2016 Sex biased expression of ghrelin and GHSR associated with sexual size dimorphism in yellow catfish. Gene 578 169-176. (doi:10.1016/j. gene.2015.12.017)

Zhou C, Zhang X, Liu T, Wei R, Yuan D, Wang T, Lin F, Wu H, Chen F, Yang S, et al. 2014 Schizothorax davidi ghrelin: cDNA cloning, tissue distribution and indication for its stimulatory character in food intake. Gene 534 72-77. (doi:10.1016/j.gene.2013.10.012)

Received in final form 5 December 2016

Accepted 20 December 2016

Accepted Preprint published online 20 December 2016 http://joe.endocrinology-journals.org

DOI: $10.1530 / J O E-16-0330$
๑) 2017 Society for Endocrinology Printed in Great Britain
Published by Bioscientifica Ltd 